\title{
Article \\ Evaluation of the Mechanical Properties of Normal Concrete Containing Nano-MgO under Freeze-Thaw Conditions by Evolutionary Intelligence
}

\author{
Mehdi Yazdchi ${ }^{1}$ (D), Ali Foroughi As1 ${ }^{1}$, Siamak Talatahari ${ }^{1,2}$ and Amir H. Gandomi ${ }^{3, *(D)}$ \\ 1 Department of Civil Engineering, University of Tabriz, 29 Bahman Blvd., Tabriz 5166616471, Iran; \\ m.yazdchi@tabrizu.ac.ir (M.Y.); Aforough@tabrizu.ac.ir (A.F.A.); talatahari@tabrizu.ac.ir (S.T.) \\ 2 Engineering Faculty, Near East University, North Cyprus, 10 Mersin, Nicosia 99138, Turkey \\ 3 Faculty of Engineering \& IT, University of Technology Sydney, Ultimo, NSW 2007, Australia \\ * Correspondence: gandomi@uts.edu.au
}

check for updates

Citation: Yazdchi, M.; Foroughi Asl, A.; Talatahari, S.; Gandomi, A.H. Evaluation of the Mechanical Properties of Normal Concrete Containing Nano-MgO under Freeze-Thaw Conditions by Evolutionary Intelligence. Appl. Sci. 2021, 11, 2529. https://doi.org/ 10.3390/app11062529

Academic Editor: Mohammad Noori

Received: 11 January 2021

Accepted: 24 February 2021

Published: 12 March 2021

Publisher's Note: MDPI stays neutral with regard to jurisdictional claims in published maps and institutional affiliations.

Copyright: (c) 2021 by the authors. Licensee MDPI, Basel, Switzerland. This article is an open access article distributed under the terms and conditions of the Creative Commons Attribution (CC BY) license (https:/ / creativecommons.org/licenses/by/ $4.0 /)$.

\begin{abstract}
In this research, different amounts of nano-MgO were added to normal concrete samples, and the effect of these particles on the durability of the samples under freeze and thaw conditions was investigated. The compressive and tensile strength as well as the permeability of concrete containing nanoparticles were measured and compared to those of plain samples (without nanoparticles). The age of concrete samples, percentage of nanoparticles, and water-to-binder ratio are the variables of the current research. Based on the results, the addition of $1 \%$ nano- $\mathrm{MgO}$ to the normal concrete with a water-to-binder ratio of 0.44 can reduce the permeability up to $63 \%$ and improve the compressive and tensile strengths by $9.12 \%$ and $10.6 \%$, respectively. Gene Expression Programming (GEP) is applied, and three formulations are derived for the prediction of mechanical properties of concrete containing nano-MgO. In this method, $80 \%$ of the dataset is used randomly for the training process and $20 \%$ is utilized for testing the formulation. The results obtained by GEP showed acceptable accuracy.
\end{abstract}

Keywords: normal concrete; nano-MgO; freeze and thaw durability; gene expression programming

\section{Introduction}

Concrete is among the most widely used materials in the construction industry owing to the ease of access to ingredients, construction in different shapes, and rapidity in operation; therefore, the life span of concrete structures is an important matter for engineers due to the economic and environmental effects of reconstruction. One of the contributing factors in the deterioration of concrete in cold regions is the repeated freeze-thaw cycles (the so-called F-T action). This repeated action causes (1) an increase in the number of microcracks, (2) a loss of mass, and (3) a reduction in the mechanical properties of the concrete. According to Powers' hydraulic pressure theory [1], the concrete is a porous material, so decreased temperature leads to the formation of ice in its pores. The formation of ice requires more volume and applies pressure to the texture of the concrete; the repetition of this action leads to the destruction of the concrete.

There are several approaches to enhance the concrete performance in freeze-thaw conditions [2]: (1) using air bubbles for providing more space for ice expansion, [3,4] (2) using fillers (micro fillers and nano fillers) and pozzolans for reducing the pores such as fly ash, silica fume, nano silica, and nano $\mathrm{MgO}$ [5], (3) using some other mechanism by applying fibers, tubes, and sheets for the prevention of crack propagation [6], and (4) using hydrophobic materials for reducing the water absorption of concrete [7]. In the current research, the second approach is chosen by using nano- $\mathrm{MgO}$, which has filler and expansive features to prevent water penetration in concrete and reduce permeability.

Permeability is one of the major destructive factors for concrete. Theoretically, nanosized particles can act as fillers, and if they are properly distributed in the concrete, they can 
fill nanosized pores and reduce the permeability; thereby, concrete resistivity to freeze-thaw action will enhance. The nano-filler effect enables nano-powders to decrease the permeability of concrete, especially by creating the interfacial transition zone (ITZ) with homogeneous texture and less porosity [8]. There are several research studies on the effect of nanomaterials on the durability of concrete in freeze-thaw condition; for instance, Wang et al. [9] have done research with different amounts of nano $\mathrm{SiO}_{2}$ in High-Performance Concrete (HPC) to investigate the resistivity of HPC against freeze-thaw conditions; they made concrete samples in three grades, $\mathrm{C} 60, \mathrm{C} 70$, and $\mathrm{C} 80$. The results showed that the additions of nano $\mathrm{SiO}_{2}$ improve compressive strength by $8 \%, 6 \%$, and $5 \%$, respectively. Fan et al. [10] added different percentages of nano-kaolinite clay to concrete. After repeated freeze-thaw cycles, they measured concrete properties such as the compressive strength and dynamic modulus of elasticity. Based on their findings, samples with 5\% kaolinite had the highest compressive strength and relative dynamic modulus of elasticity following 125 freeze-thaw cycles. In 2016, Gonzalez et al. [11] added nano-silica to Portland cement concrete (PCC) to fulfill this aim. They reported that nano-silica improved the compressive strength as well as paste density and reduced the external damage of samples subjected to freeze-thaw cycles. In Reference [12], nano additives with graphite were added to concrete to study the concrete characteristics such as the compressive strength and thermo-frost resistivity. The findings showed that using nano additives improved the properties of concrete. Shahrajabian and Behfarnia [13] analyzed the effect of nano-silica, nano-alumina, and nano-clay on the durability of alkali-activated slag (AAS) concrete samples subjected to freeze-thaw cycles. Their results showed that nano-silica and nano-clay improved the concrete durability more than nano-alumina. In the experimental study [14], the effect of nano-powders on the mechanical properties and freeze-thaw resistance of shotcrete was investigated; in this regard, nano-clay and nano-silica were used, and different percentages of the mentioned nano-powders were replaced with the cement. According to the results, using $6 \%$ of nano-silica played an effective role in the frost resistance of shotcrete. Adding nano clay had less impact on the improvement of mechanical properties in comparison to the nano-silica, but it was more effective in comparison with the control sample. Another type of materials that have an effective role in the reduction of permeability of concrete is $\mathrm{MgO}$. This type of material has an expanding feature that means that during the completion of the hydration process of $\mathrm{MgO}$, the product occupies a larger volume that fills the pores and micro-cracks of concrete. The usage of $\mathrm{MgO}$ in conventional Portland cements results in the production of $\mathrm{Mg}(\mathrm{OH})_{2}$ i.e.,

$$
\left(\mathrm{MgO}+\mathrm{H}_{2} \mathrm{O} \rightarrow \mathrm{Mg}(\mathrm{OH})_{2}\right)
$$

and its subsequent carbonation

$$
\left(\mathrm{Mg}(\mathrm{OH})_{2}+\mathrm{CO}_{2}+2 \mathrm{H}_{2} \mathrm{O} \rightarrow \mathrm{MgCO}_{3} \cdot 3 \mathrm{H}_{2} \mathrm{O}\right)
$$

increases hydrated magnesium carbonates. Due to the long-term instability observed in concrete with a high amount of $\mathrm{MgO}$, standards limited the usage of $\mathrm{MgO}$ in cement and concrete [15].

$\mathrm{MgO}$ is used as an additive in mass concrete and has been utilized widely for more than 40 years in concrete dams. Regarding the effect of high temperature on mass concrete, thermal shrinkage is inevitable, and $\mathrm{MgO}$ plays a role as an expansive additive to compensate for the thermal shrinkage. While the usage of $\mathrm{MgO}$ reduces thermal shrinkage, it helps to speed up the construction process as well [16]. The delayed expansion of $\mathrm{MgO}$ recovers the thermal shrinkage of concrete due to delayed hydration. An appropriate amount of $\mathrm{MgO}$ can prevent the formation of micro-cracks, but an excessive amount of $\mathrm{MgO}$ produces high inner pressure, which destroys the structure of concrete and deteriorates mechanical properties such as the compressive strength and permeability. In an experimental study [17], nano-MgO was utilized in cement mortar to investigate its effect on the compressive strength of cement mortar samples. They reached the result that 
samples with nano-MgO have a denser microstructure, and for this reason, they have a higher compressive strength than plain samples.

In the current research, nano- $\mathrm{MgO}$ as an additive is mixed with the normal concrete paste. According to previous research studies [18,19], it has expanding properties, and an appropriate amount of this nanomaterial can have an efficient role in enhancing the mechanical properties of concrete such as permeability. In previous research studies about nano- $\mathrm{MgO}$, the freeze-thaw condition was not studied, while this study covers this matter by investigating the freeze-thaw resistivity of concrete.

In addition to the experimental work, it is important to propose a mathematical model that is able to predict concrete features. Gene expression programming (GEP) is a powerful numerical algorithm that is selected in the present research to fulfill this aim. GEP is basically similar to genetic algorithms (GAs) and genetic programming (GP) [20]. However, it is an extended version of GA and GP, which are inspired by Darwin's theory of "survival of the fittest". Similar to GA and GP, GEP uses different evolutionary mechanisms such as cross over, mutation, and reproduction to generate new individuals [21]. The differences among the three algorithms stem from the nature of the individuals. In GAs, the individual has a fixed length in linear strings (chromosomes); in contrast, the individuals in the GP are nonlinear entities of different sizes and shapes (parse trees), while the individuals in GEP are made as linear strings of fixed length (the genome or chromosomes) that are then expressed as nonlinear entities of different sizes and shapes (simple diagram representations or expression trees) [22]. It has been reported that the model generated by GEP is superior to other regression techniques. In regression techniques, the function is analyzed once it is defined, whereas, in the GEP method, there is no predefined function. Moreover, GEP has a more powerful performance compared to other regression methods and Artificial Neural Network (ANN), [23].

Many studies utilize GEP for engineering problems. Deriving a model for the flow number of dense asphalt-aggregate mixtures was the topic of a research study in 2011 [24]. The results indicated that the proposed model has a high ability of evaluation of the flow number of asphalt mixtures. In Ref. [25], the GEP formulation for predicting the splitting strength of cylindrical samples was developed. Data gained from predicting the formula were compared with real experimental data and other formulas from some well-known standards. In 2012, a prediction model for the compressive strength of concrete under triaxial loading was proposed by Gandomi et al. [26]. They used GEP for this purpose, and the derived model had a superior performance comparing with empirical models. In 2014, a design equation for the shear strength of slender RC beams was derived by GEP [27]. The proposed formulation was compared to the formulation that was recommended by several building codes, and the GEP code was found to be more accurate. In 2015, Alkroosh and Ammash [28] used a GEP-based method to predict the punching shear strength of normal and high strength reinforced concrete flat slabs. They applied 58 case stories that measured the punching shear strength; it was shown that the model proposed by GEP has high accuracy and ability to define the important parameters, which significantly influenced the punching shear strength. In the other study [29], different cement strength classes were used to prepare the samples, and their compressive strengths were measured. The results indicated the strong potential of GEP in predicting the compressive strength of cement mortar. In Shahmansouri et al. [30], GEP is used to predict the compressive strength and electrical resistivity of concrete with natural zeolite. They stated that GEP is capable of predicting the considered properties with a high accuracy. Iqbal et al. [31] used waste foundry sand in the concrete and applied GEP as a tool for predicting the mechanical properties of concrete. They also compared the GEP model with other regression techniques and proved that it has high accuracy and potential for prediction. Behnia et al. [32] developed a model for predicting the static modulus of elasticity and uniaxial compressive strength (UCS) by a GEP method, and for this purpose, 42 datasets from previous studies were utilized. Of these, 22 sets were considered for training, and the rest were used for testing. In the other recent study [33], GEP was utilized to predict the compressive strength 
of geopolymer mortars with ferrosialate basement. Two GEP models were proposed in this research that both have a good fit with real data. According to the lack of an evolutionary intelligence method in previous research studies about the effect of nano- $\mathrm{MgO}$ on concrete, the current research utilizes GEP to produce a mathematical formula that is applicable for civil engineers for designing purposes or the prediction of the mechanical properties of concrete containing nano-MgO in the freeze-thaw condition.

\section{Materials and Methods}

\subsection{Materials}

In this study, a cement type 2 with a density of $3.15 \mathrm{gr} / \mathrm{cm}^{3}$ and blaine fineness of $3210 \mathrm{~cm}^{2} / \mathrm{gr}$ (confirming ASTM C150 [34]) was utilized in all mixes. The related properties are presented in Table 1.

Table 1. Chemical composition and properties of cement type 2.

\begin{tabular}{cc}
\hline Chemical Analysis (\%) & Cement Type 2 Portland \\
\hline $\mathrm{CaO}$ & 63.35 \\
$\mathrm{SiO}_{2}$ & 21.32 \\
$\mathrm{Fe}_{2} \mathrm{O}_{3}$ & 3.77 \\
$\mathrm{MgO}^{2-}$ & 2.44 \\
$\mathrm{SO}_{3}^{2-}$ & 1.98 \\
$\mathrm{Na}_{2} \mathrm{O}$ & 0.24 \\
$\mathrm{~K}_{2} \mathrm{O}$ & 0.63 \\
$\mathrm{Cl}^{-}$ & 0.01 \\
Blaine $\left(\mathrm{cm}^{2} / \mathrm{g}\right)$ & 3210 \\
\hline
\end{tabular}

Fine and coarse aggregates were extracted from a local mine. Grading tests were done on the coarse and fine aggregates, and results are shown in Table 2; Table 3. According to Table 3, the fine aggregate is coarse-grained (sieve No. 4 has $17 \%$ remaining mass), and the fineness modulus is 3.8. Therefore, fine aggregates are modified to reduce the fineness modulus to meet the recommended amount in the standard of ASTM C33, [35]. In this regard, the aggregates of sieve No. 4 and half of sieve No. 8 were assumed as a part of coarse aggregates. This matter is considered in the mixture designation of concrete, and the required water content of concrete is modified due to this issue.

Table 2. Grading of coarse aggregates.

\begin{tabular}{ccccc}
\hline Sieve No. (BS) & $\begin{array}{c}\text { Remaining Mass on } \\
\text { Sieve (gr) }\end{array}$ & $\begin{array}{c}\text { Remaining Mass on } \\
\text { Sieve (\%) }\end{array}$ & $\begin{array}{c}\text { Cumulative Fraction } \\
\text { Passing (\%) }\end{array}$ & $\begin{array}{c}\text { Cumulative Fraction } \\
\text { Remaining (\%) }\end{array}$ \\
\hline $1^{\prime \prime}$ & 0 & 0 & 100 & 0 \\
$3 / 4^{\prime \prime}$ & 150 & 5 & 95 & 5 \\
$1 / 2^{\prime \prime}$ & 1000 & 33.4 & 61.6 & 38.4 \\
$3 / 8^{\prime \prime}$ & 870 & 29 & 32.6 & 67.4 \\
$\# 4$ & 930 & 31.1 & 1.5 & 98.5 \\
Pan & 40 & 1.3 & 0 & 100 \\
\hline
\end{tabular}

Table 3. Grading of fine aggregates.

\begin{tabular}{cccc}
\hline Sieve No. & Remaining Mass (gr) & Remaining Mass (\%) & $\begin{array}{c}\text { Cumulative Fraction } \\
\text { Remaining }\end{array}$ \\
\hline$\# 4$ & 170 & 17 & 17 \\
$\# 8$ & 280 & 28.5 & 45.5 \\
$\# 16$ & 140 & 14.2 & 59.7 \\
$\# 30$ & 180 & 18.3 & 78 \\
$\# 50$ & 130 & 13.2 & 91.2 \\
$\# 100$ & 70 & 7.1 & 98.3 \\
\hline
\end{tabular}


Nano-MgO particles are used as admixture by the percentage of cement weight. The nanoparticles are less than $40 \mathrm{~nm}$, and the density of nano- $\mathrm{MgO}$ is $3.58 \mathrm{~g} / \mathrm{cm}^{3}$ with a purity of $99 \%$. Table 4 presents the details of nano-MgO analysis.

Table 4. Chemical properties of nano-powder.

\begin{tabular}{cccc}
\hline \multicolumn{4}{c}{ Magnesium Oxide Nano-Powder (MgO) Certificate of Analysis } \\
\hline $\mathrm{MgO}$ & $\mathrm{Na}$ & $\mathrm{K}$ & $\mathrm{Ca}$ \\
\hline$>99 \%$ & $<750 \mathrm{ppm}$ & $<218$ & $<760$ \\
\hline
\end{tabular}

\subsection{Mixture and Sample Preparation}

In this study, 98 cubic concrete samples $(10 \times 10 \times 10 \mathrm{~cm})$ and 78 cylindrical concrete samples $(10 \times 20 \mathrm{~cm})$ are made with different percentages of nano-MgO. The amount of nano-MgO in concrete is specified by the percentage of the cement weight. The assumed amounts of nano- $\mathrm{MgO}$ are $0 \%, 0.5 \%, 1 \%$, and $1.5 \%$ of the cement weight. For the regular and identical distribution of nanoparticles in the mixture, they should be used in a solution form; otherwise, the mixture leads to agglomeration, entailing an inevitable reduction in the mechanical properties of concrete. In this regard, an ultrasonic stirring instrument is used, and different amounts of nano-MgO are dissolved at a high speed in water for $5 \mathrm{~min}$ [36]. This solution is added to the mixture and stirred for $3 \mathrm{~min}$ to reach uniform nano-powder dispersion. Finally, the concrete mixture is poured into cubic and cylindrical molds. The molds are filled with concrete over three steps. Three or $4 \mathrm{~cm}$ of the mold height is filled with concrete in each step and vibrated for $5 \mathrm{~s}$ to remove the air voids. Figure 1 shows fresh concrete in molds.

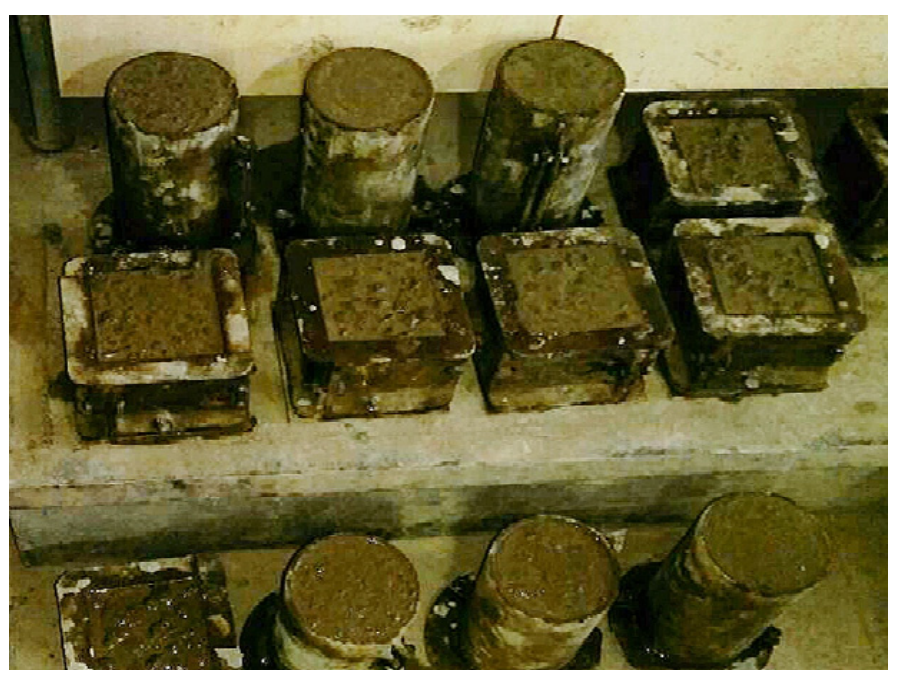

Figure 1. Fresh concrete in cubic and cylindrical molds.

Samples without nano-powder are called plain samples or control samples, which are used to compare the effect of nano- $\mathrm{MgO}$ on the mechanical properties of the concrete. The other variable was water-to-binder ratio. Samples with three water-to-binder ratios $(0.44$, 0.49 , and 0.62 ) were prepared and subjected to the curing process. To cure the samples, a water tank with a temperature of $23 \pm 2{ }^{\circ} \mathrm{C}$ is utilized and concrete samples are placed in a water tank for 7, 28, and 56 days. The variables of the samples are presented in Table 5. 
Table 5. Properties and variables of experimental samples.

\begin{tabular}{ccccc}
\hline Type of Samples & Water-to-Binder Ratio & $\begin{array}{c}\text { Percentage of } \\
\text { Nano-MgO }\end{array}$ & Super Plasticizer & Curing Period \\
\hline Cubic samples & 0.44 & & & \\
$(10 \times 10 \times 10)$ & 0.49 & $0 \%, 0.5 \%, 1 \%, 1.5 \%$ & $0 \%, 0.5 \%, 1 \%$ & $7,28,56$ days \\
\hline Cylinder samples $(10 \times 20)$ & 0.62 & & & \\
\hline
\end{tabular}

\subsection{Experimental Tests}

\subsubsection{Freeze-Thaw Test}

To investigate the effect of nano- $\mathrm{MgO}$ on the freeze-thaw resistivity of concrete samples, a rapid freeze-thaw machine is required to simulate the periodic freeze-thaw cycles in nature. In this connection, we utilized a programmable freeze-thaw machine that is capable of determining the freeze-thaw time periods according to ASTM C666 [37]. There are two procedures for performing the freeze-thaw experiment: (A) rapid freezing and thawing in water and (B) rapid freezing in air and thawing in water. In this research, procedure $A$ is selected. The nominal temperatures for freezing and thawing are the same for both procedures, and the temperature of the sample is decreased until $18{ }^{\circ} \mathrm{C}$ and raised up to $4{ }^{\circ} \mathrm{C}$. According to the guideline, the procedure should take between 2 and $5 \mathrm{~h}$. Furthermore, the thawing time should be at least $25 \%$ of one cycle time. At the end of the cooling and heating procedures, the temperature in the center of the sample should be $-18 \pm 2{ }^{\circ} \mathrm{C}$ and $4 \pm 2{ }^{\circ} \mathrm{C}$, respectively. A thermometer is installed in the center of a cubic $(10 \times 10 \times 10)$ sample. This method ensures accuracy regarding the temperature of the sample's center. The sensors are connected to a computer that controls the temperatures; for example, when the temperature reaches $-18^{\circ} \mathrm{C}$, it stops the freezing process and starts the heating process up to $4{ }^{\circ} \mathrm{C}$ and vice versa. Concrete samples are placed in molds containing $3 \mathrm{~mm}$ water around the samples, and all samples are subjected to 300 freeze-thaw cycles. Figure 2 shows the cubic and cylindrical samples.

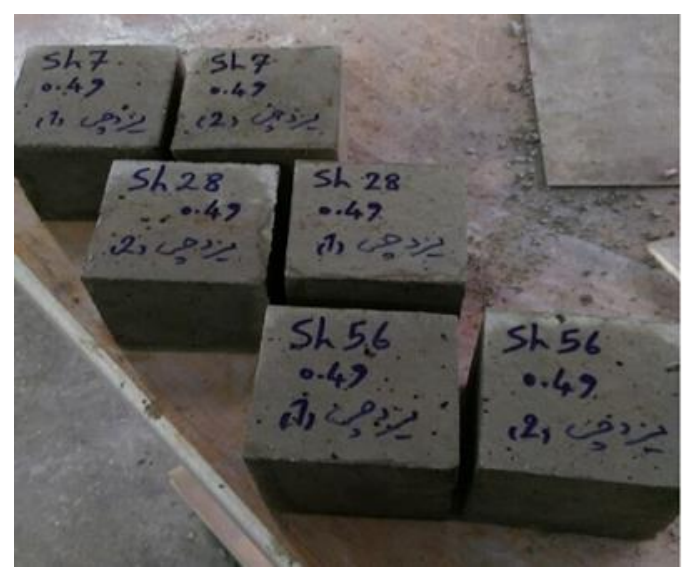

(a)

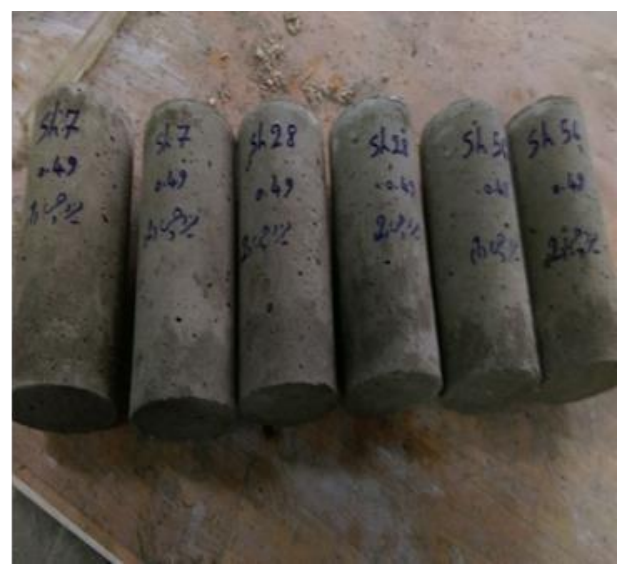

(b)

Figure 2. Concrete samples: (a) cubic samples, (b) cylindrical samples.

\subsubsection{Compressive Test}

The compressive test is performed using the cubic $10 \mathrm{~cm}$ samples. The compressive test shows the general properties of concrete; it determines whether the concrete is acceptable for special usage or not. The process is done by using a compressive test machine that has two parallel plates; the sample is placed between two plates, while the upper plate comes down at a steady rate. The rate of load velocity applied to the specimens is $140 \mathrm{~kg} / \mathrm{cm}^{2} / \mathrm{min}$. 
The loading continued until the failure of the specimens. Figure 3 demonstrates a cubic sample under the compressive test machine.

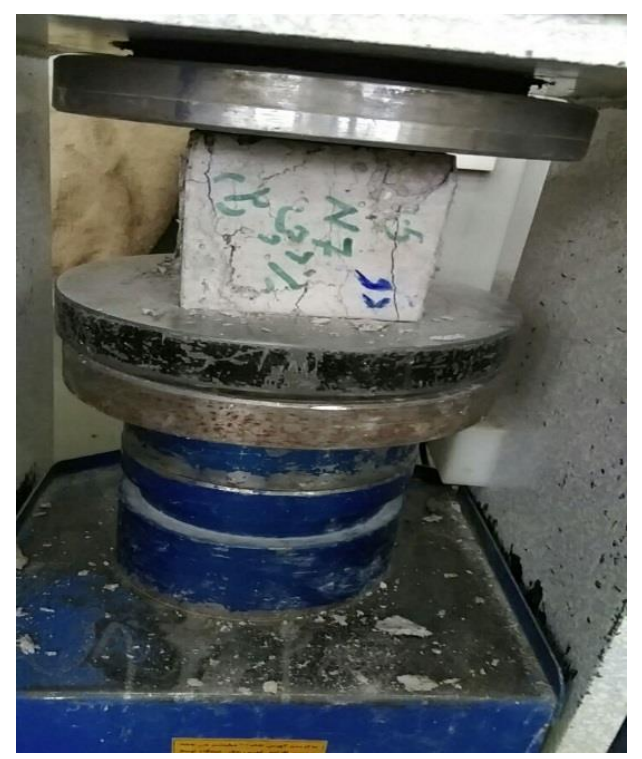

Figure 3. A cubic sample during the compressive strength test.

\subsubsection{Tensile Test}

The splitting tensile test is a method for measuring the tensile strength of cylindrical concrete samples. This test is done according to ASTM C496 [38]. The splitting tensile test machine is applied by the load within a range of 0.7 to $1.4 \mathrm{MPa} / \mathrm{min}$ at a constant rate without any shock. To ensure that the load is uniformly imposed on the sample, two wooden sticks are put on the bottom and top of the samples (Figure 4).

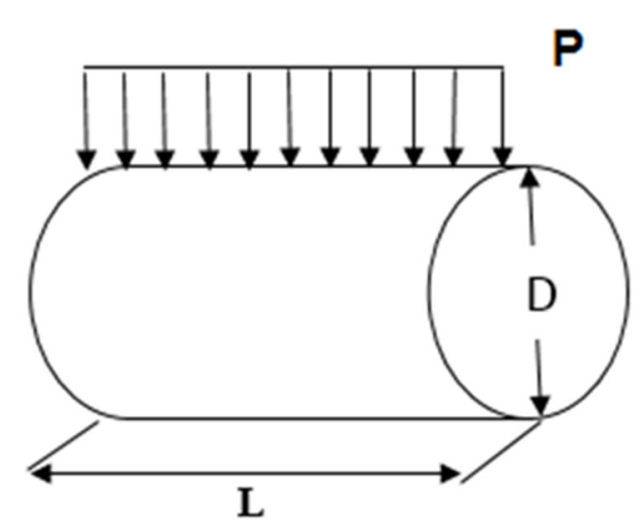

(a)

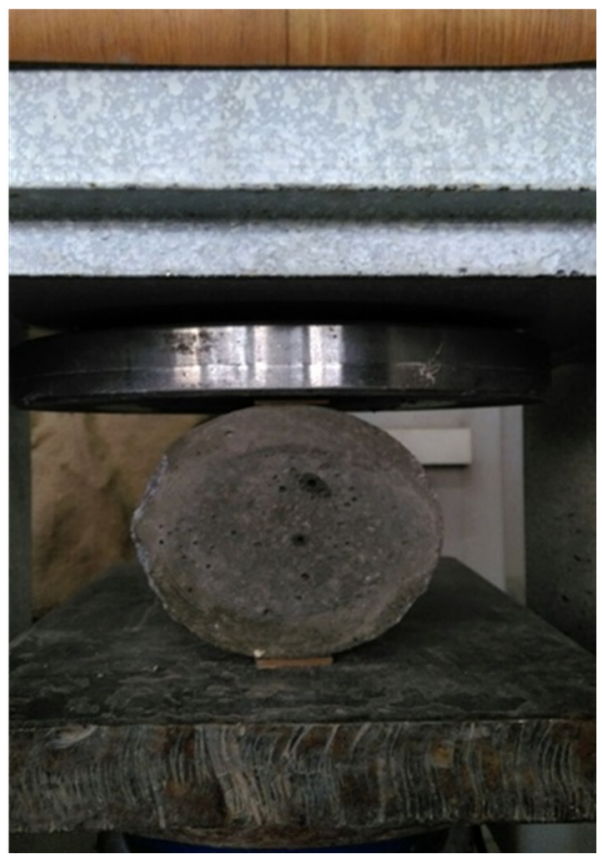

(b)

Figure 4. (a) Schematic diagram of the splitting test, (b) a cylindrical concrete sample during the splitting test. 
The tensile strength of the specimen can be calculated as follows:

$$
T=2 P /(\pi L D)
$$

where $T$ is the splitting tensile strength (MPa), $P$ is the maximum force indicated by the testing machine before the failure of the specimen $(\mathrm{N}), L$ is the length of the specimen $(\mathrm{mm})$, and $D$ is the diameter of the specimen $(\mathrm{mm})$. Figure 4a shows the parameters of this equation in a schematic form.

\subsubsection{Permeability Test}

The water permeability test is also applied to the cylindrical samples according to the standard of DIN 1048 [39]. At the end of the curing period, the specimens are put in a freeze-thaw chamber and subjected to 300 cycles of the freezing and heating action. The samples are dried in an oven for $24 \mathrm{~h}$ and then placed in a permeability apparatus under 5 bar pressure of water for $24 \mathrm{~h}$. Afterwards, the splitting test is performed, and the length of the water penetration is measured (Figure 5).

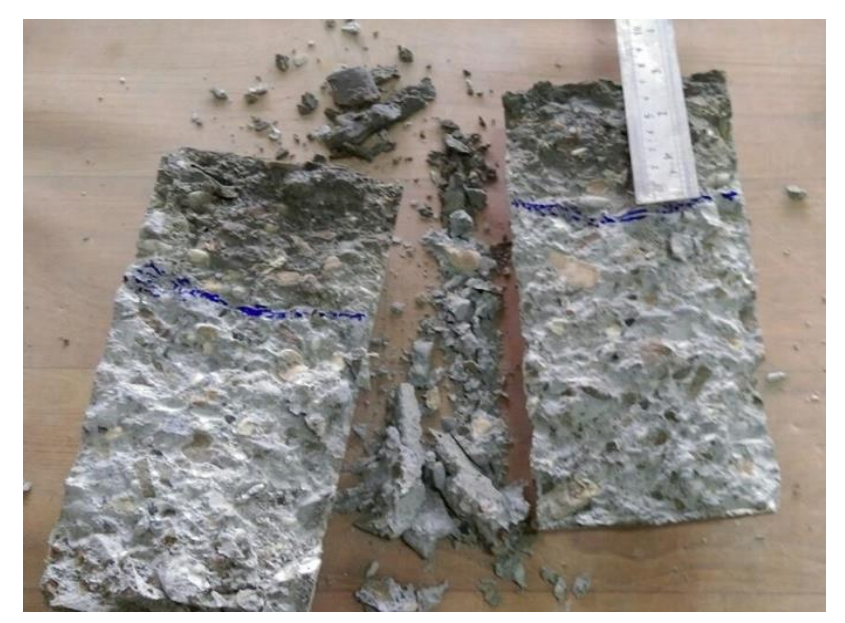

Figure 5. Measuring water penetration in the cylindrical sample.

\section{Evolutionary Intelligence Method}

The GEP method was used to find a mathematical formula between the parameters and properties of concrete samples containing nano- $\mathrm{MgO}$ particles under the freeze-thaw condition. This section describes this method briefly.

\subsection{Gene Expression Programming}

As proposed by Ferriera [40], Gene Expression Programming (GEP) is an extension of genetic programming (GP) and genetic algorithm (GA) models. In GEP, primary chromosomes are created from characters. Genes have a fixed length, and the used language is called the Karva language (K-language). GEP is able to translate the K-language to expression trees (ETs). ETs are a type of diagram that shows mathematical relations. They look similar to a tree. On the leaf of the tree (nodes), operators or variables are placed. Each node could have one or more sub-nodes. The reading order is from left to right and top to bottom as we read the text. Figure 6 shows the ET of expression $\frac{a-b}{c} \times \sqrt{d+e}$. 


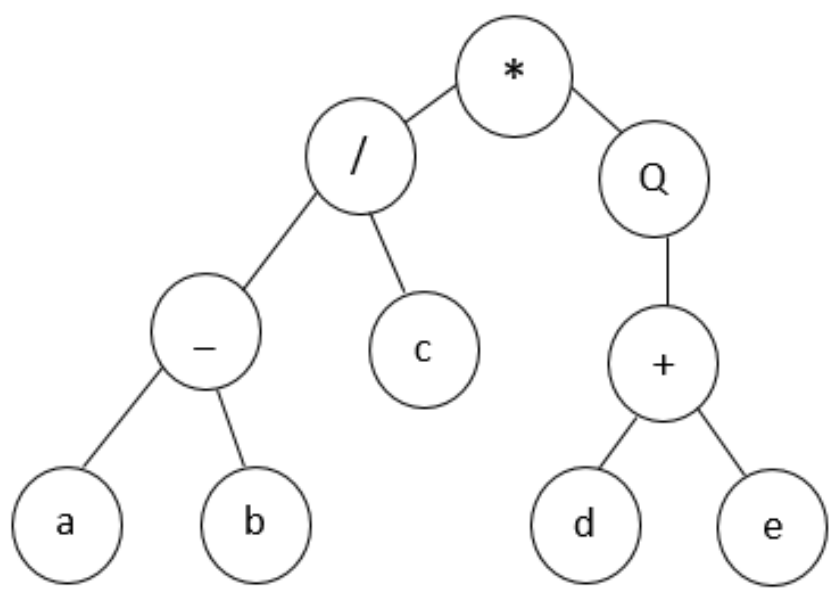

Figure 6. Expression tree of the chromosome (ET).

Then, the genotype or k-expression of Figure 6 can be derived as follows: 0123456789

*/Q-c+abde.

In this genotype, $Q$ represents the square root function and " $a, b, c, d, e$ " are arguments. The genotype comprises two parts: head (containing functions and terminals) and tail (only containing terminals). For example:

012345678901234567890

*ba-Qbaa+babbabaabbab.

The italic part is the gene head, and the ET ends at position 8, while the gene ends at position 20. It is obvious that the maximum size of the ET is equal to the size of the gene, but it can be smaller. By linking functions, several genes can assemble and build a chromosome. In other regression models, certain functions are defined beforehand, while there is no predefined function in GEP. It is also believed that GEP is more applicable to solve multivariable problems compared to other techniques [40]. Each ET created by GEP is mathematically meaningful, whereas in the GP, a new offspring is not necessarily correct. This important point makes GEP more efficient than the GP. To create new individuals, the regular operations of GA and GP are also applicable to GEP. Mutation, crossover, recombine, transpose, and replication are these operations. Figure 7 depicts the flow-chart of GEP [40]. To obtain highly accurate results, effective parameters should be defined. To solve a problem, a chromosome with one gene is utilized. By adding to the head length and making multi-gene functions, it is possible to have a solution with a high accuracy; the operations between genes in a solution are defined by the linking functions. Linking functions are addition, subtraction, multiplication, and division.

In this research, the terminals are independent variables as:

$$
\mathrm{W} / \mathrm{C}, \mathrm{NMgO}, \mathrm{CP}, \mathrm{SP}
$$

where $\mathrm{W} / \mathrm{C}$ is the water-to-binder ratio (water-to-cementitious material ratio), $\mathrm{NMgO}$ is the percentage of nano- $\mathrm{MgO}, \mathrm{CP}$ is the curing period, and $\mathrm{SP}$ is the percentage of the superplasticizer. Four basic algebraic operators $(+,-, \times, /)$ and other operators (Sqrt, $\mathrm{Ln}, \wedge^{2} \ldots$ ) are applied in the models. The third step is to specify the properties of the chromosomes such as the head length and the gene number. In this research, three genes and a head length of 6 were assumed. The fourth step is to define the linking functions; here, "addition" and "multiplication" are selected as linking functions for connecting sub-ETs with each other. The fifth step is choosing genetic operations such as mutation, transposition, and crossover. 


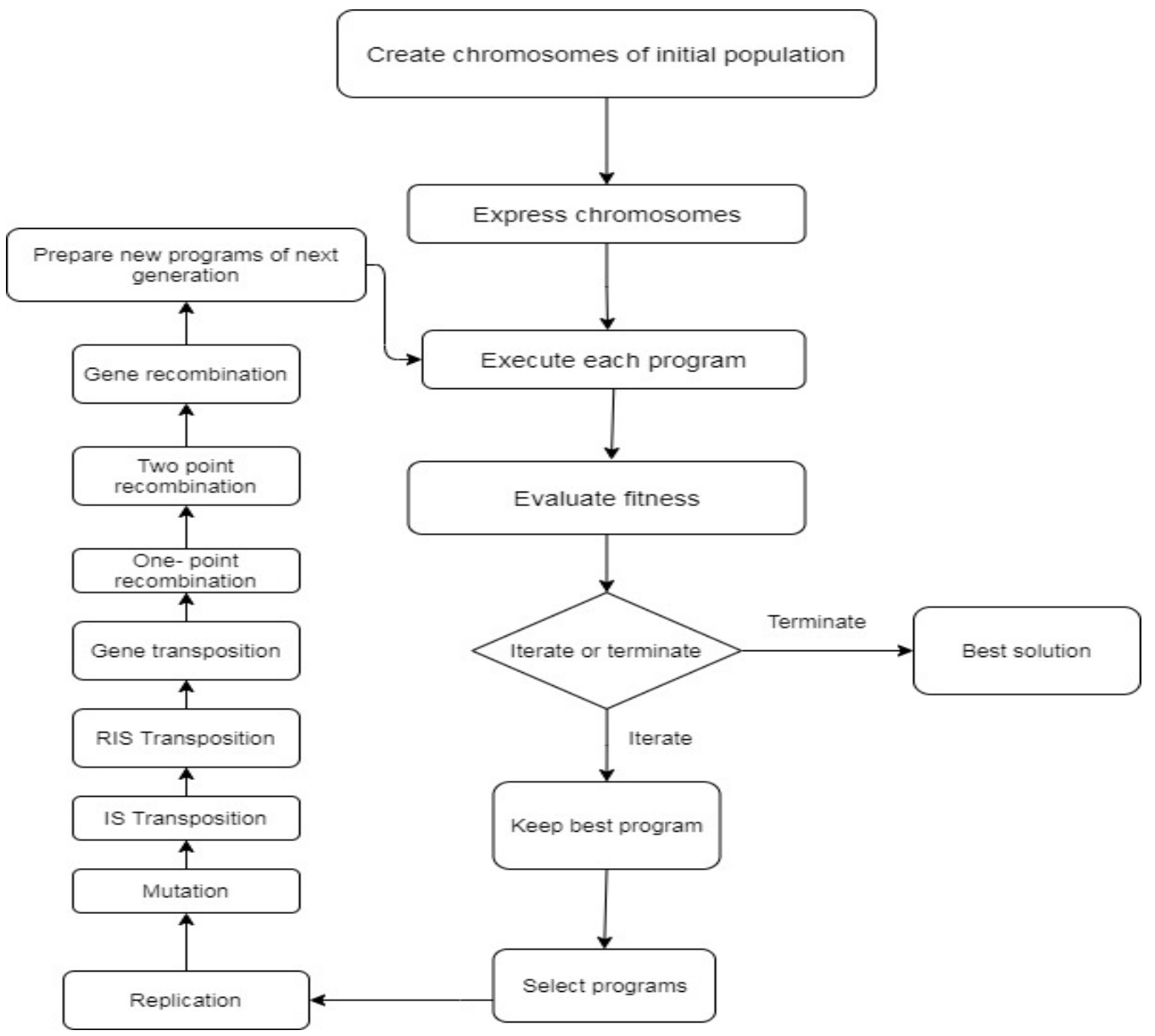

Figure 7. The flow-chart of Gene Expression Programming.

\subsection{Required Data for Modeling}

In this research, the required data for GEP (in the training and testing) are associated with the compressive strength of 98 cubic samples $(10 \mathrm{~cm})$, while 78 cylindrical $(10 \times 20)$ samples are used for the tensile strength and permeability models obtained by the experimental tests. The concrete samples are fabricated by different percentages of nano- $\mathrm{MgO}$ under 300 freeze-thaw cycles. Table 6 illustrates the model variables as input data and concrete properties as output data and their range of values.

Table 6. Input and output variables and range of variance.

\begin{tabular}{cccc}
\hline Input Variables & Range of Variation & Output Variables & Range of Variables \\
\hline Water-to-binder ratio & $0.44-0.62$ & $\begin{array}{c}\text { Compressive strength } \\
\left(\mathrm{kg} / \mathrm{cm}^{2}\right)\end{array}$ & $305-661$ \\
\hline Curing Age (day) & $7-56$ & $\begin{array}{c}\text { Tensile strength } \\
\left(\mathrm{kg} / \mathrm{cm}^{2}\right)\end{array}$ & $20-56$ \\
\hline Nano-MgO \% & $0-1.5$ & Permeability $(\mathrm{cm})$ & $2.4-11$ \\
\hline Super Plasticizer \% & $0-1$ & &
\end{tabular}

The input variables of the model are water-to-binder ratio, nano-MgO percentage, curing period, and percentage of superplasticizer. Randomly, $80 \%$ of the dataset is used for training and $20 \%$ is used for testing. Fitness function is necessary for assessing the accuracy 
in every program, and in this research, the root mean square error (RMSE) is assumed as the fitness function. According to Equation (3), the RMSE can be calculated:

$$
R M S E=\sqrt{\frac{1}{n} \sum_{i=1}^{n}\left(p_{i}-e_{i}\right)^{2}}
$$

where $p$ is the prediction value, $e$ stands for experimental values, and $n$ is the number of specimens.

Several models with different amounts of head size, number of chromosomes, and number of genes were examined. Higher amounts of head size and a higher population of chromosomes lead to the higher complexity of the model, which prolongs the time it takes for the programs to run; also, high complexity does not lead to a highly accurate model necessarily. The proper amounts of head size, number of chromosomes, and other parameters are obtained by the trial-and-error method. As a result, eight models are chosen due to the best $\mathrm{R}^{2}$ values. Table 7 presents the properties of these models. The program was run until there was no longer a significant improvement in the performance of the model.

Table 7. Properties of different Gene Expression Programming (GEP) models.

\begin{tabular}{|c|c|c|c|c|c|c|c|c|}
\hline Model's Properties & GEP 1 & GEP 2 & GEP 3 & GEP 4 & GEP 5 & GEP6 & GEP 7 & GEP 8 \\
\hline $\begin{array}{c}\text { Number of } \\
\text { chromosomes }\end{array}$ & 30 & 30 & 30 & 30 & 35 & 35 & 35 & 35 \\
\hline Number of head size & 8 & 8 & 8 & 8 & 10 & 10 & 10 & 10 \\
\hline Number of genes & 3 & 3 & 3 & 3 & 3 & 3 & 3 & 3 \\
\hline Linking function & Addition & Addition & $\begin{array}{l}\text { Multipli- } \\
\text { cation }\end{array}$ & $\begin{array}{l}\text { Multipli- } \\
\text { cation }\end{array}$ & Addition & Addition & $\begin{array}{l}\text { Multipli- } \\
\text { cation }\end{array}$ & $\begin{array}{l}\text { Multipli- } \\
\text { cation }\end{array}$ \\
\hline Constant per gene & 1 & 2 & 1 & 2 & 1 & 2 & 1 & 2 \\
\hline
\end{tabular}

\section{Results and Discussion}

The experimental and modeling results are summarized and presented in this section.

\subsection{Compressive Strength}

In this research, 98 cubic $(100 \mathrm{~mm})$ concrete samples are made, and the compressive strength of the specimens is measured. Since several samples were constructed with the same percentage of materials, the mean compressive strength of the specimens is used in Figure 8, which includes three diagrams for three water-to-binder ratios: (a) 0.44 , (b) 0.49 , and (c) 0.62 .

For specimens with a water-to-binder ratio of 0.44 and a curing period of 56 days, the mean value of the compressive strength reaches $6.20 \mathrm{MPa}$ for samples with $0.5 \%$ nano-MgO, showing a $7.4 \%$ increase in comparison to the control samples. With the same percentage of materials, the mean compressive strength reaches $6.30 \mathrm{MPa}$ for samples with $1 \%$ nano-MgO, which is $9.12 \%$ more than the control samples. As observed in Figure $8 \mathrm{a}, \mathrm{b}$, in all cases, there is a positive effect of nano-MgO on compressive strength. By increasing the water-to-binder ratio, the effect of nano- $\mathrm{MgO}$ becomes clearer. The role of nano- $\mathrm{MgO}$ on the compressive strength of the samples is different depending on the water-to-binder ratio. For instance, when the water-to-binder ratio is 0.44 , the maximum compressive strength is belonging to samples with $1 \%$ nano-MgO. It is noteworthy that the same amount of nano-MgO in samples with a higher water-to-binder ratio leads to a smaller compressive strength. It seems that there are two reasons for this behavior. The first one is that nano- $\mathrm{MgO}$ has an expansive feature which means the production of hydration needs more space; therefore, excessive pressure is created in the texture of concrete by the completion of the hydration process. The other reason is related to the high specific surface of nano-MgO. Regarding this matter, during the dispersion process, nano- $\mathrm{MgO}$ can be swelled, which increases the 
viscosity of suspension, and as a result, when the amount of nanomaterial is growing, the uniform dispersion of nano-MgO becomes difficult. By non-uniform dispersion of nano$\mathrm{MgO}$, the agglomeration will be inevitable, and compressive strength can be decreased. Figure 8 shows the standard deviation (STD) for compressive strength data, as well. In statistics, the standard deviation is a factor that means how the dataset is dispersed and shows that every piece of data tends to be close to the mean value.

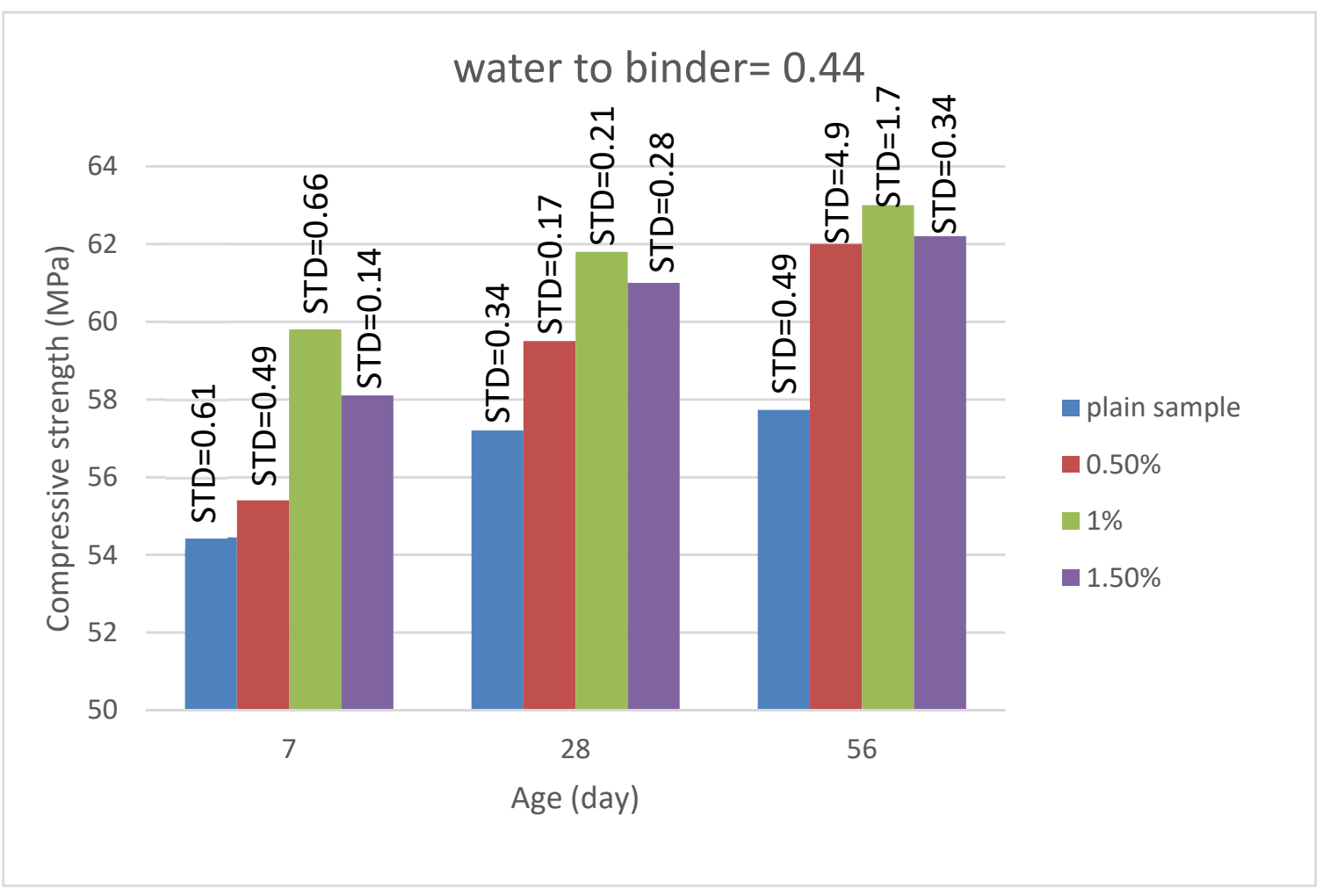

(a)

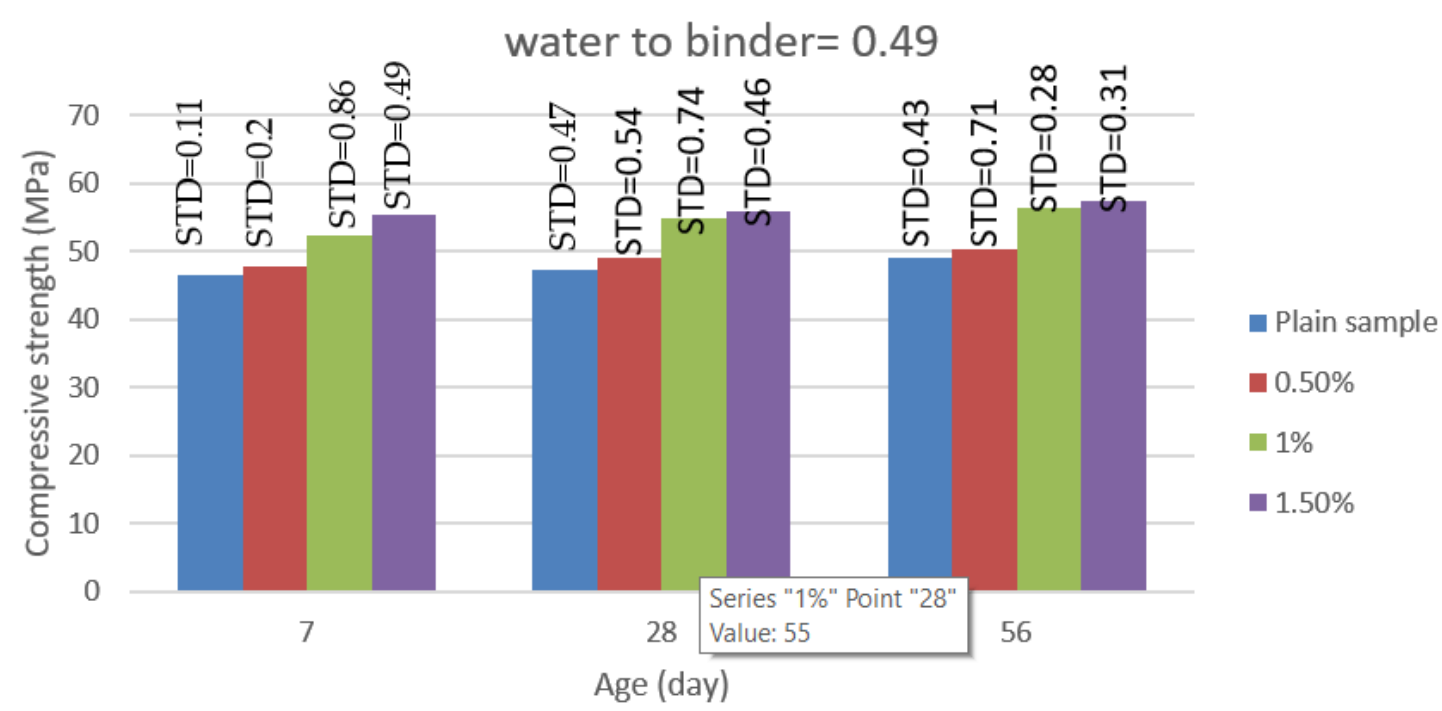

(b)

Figure 8. Cont. 


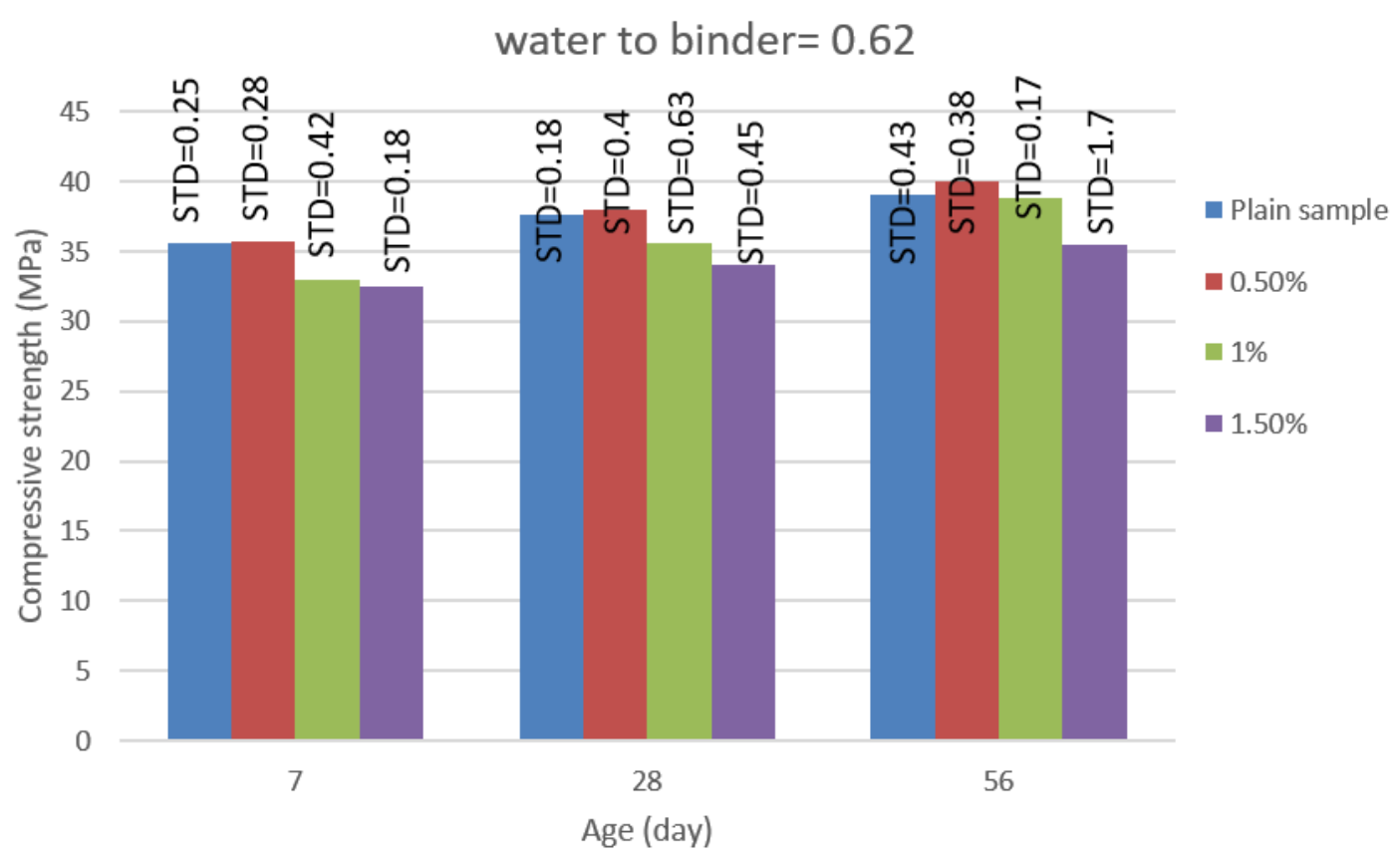

(c)

Figure 8. Compressive strength vs. age of concrete for water-to-binder ratios of (a) 0.44, (b) 0.49, and (c) 0.62.

\subsection{Tensile Strength}

The results of the splitting test are shown in Figure 9a-c for water-to-binder ratios of $0.44,0.49$, and 0.62 , respectively. The improvement trend of tensile strength is the same as the compressive strength. The highest tensile strength $(4.9 \mathrm{MPa})$ is about $10.6 \%$ more than the control samples belonging to the samples with water-to-binder ratio of 0.44 and replacement of $1 \%$ nano- $\mathrm{MgO}$ after 56 days of curing. Maximum improvement in the tensile strength for a water-to-binder ratio of 0.49 is obtained by replacing $1.5 \%$ nano- $\mathrm{MgO}$ after 56 days of curing; the tensile strength is $4.3 \mathrm{MPa}$, which is $3.3 \%$ more than the control samples. As discussed in the previous section, the expanding effect of nano-MgO causes excessive inner pressure after the completion of hydration, which leads to the creation of micro-cracks in higher percentages of nano-MgO usage. The other result of Figure 9 is that the optimum amount of nano-MgO differs by variation of the water-to-binder ratio. For example, the optimum amount of nano- $\mathrm{MgO}$ for a water-to-binder ratio of 0.44 and 0.49 is $1 \%$ and $1.5 \%$, respectively. While for a water-to-binder ratio of 0.62 , the optimum amount is $0.5 \%$, and the reason can be because of the high viscosity of the fresh concrete mixture due to high special surface of nano-MgO. The viscosity becomes extensively high at higher water-to-binder ratios, which can be the reason for the non-uniform dispersion of nano-MgO, which decreases the compressive and tensile strength. 


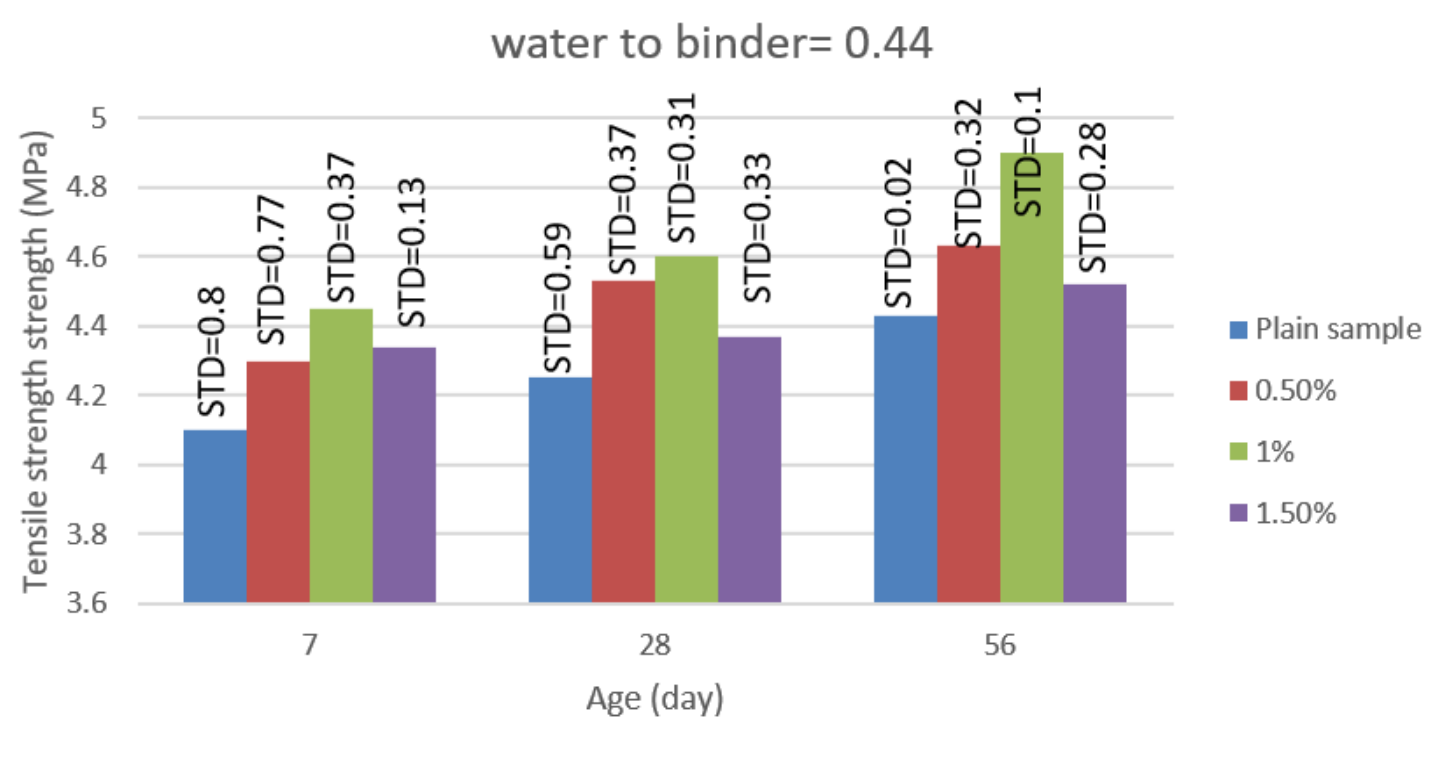

(a)

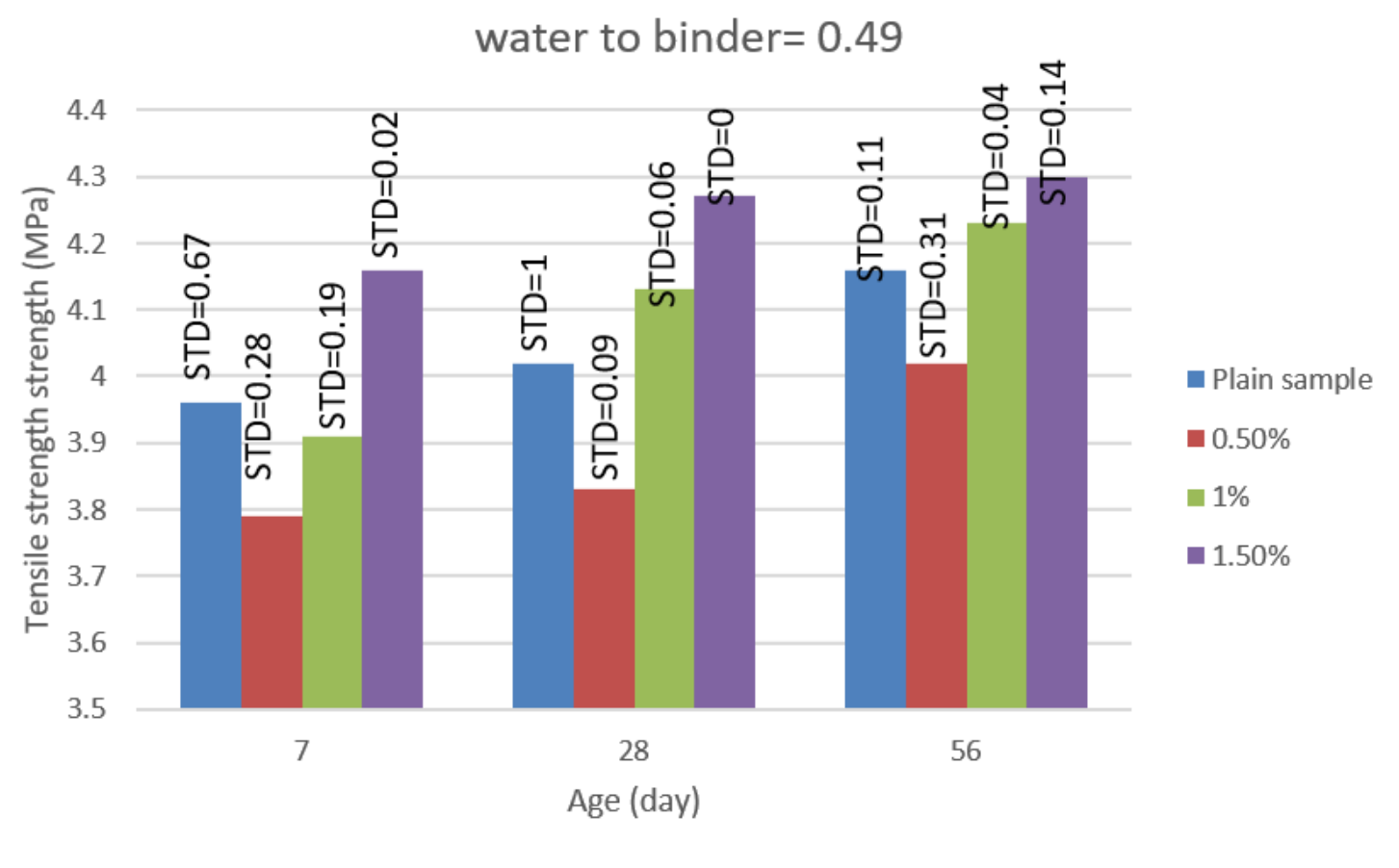

(b)

Figure 9. Cont. 


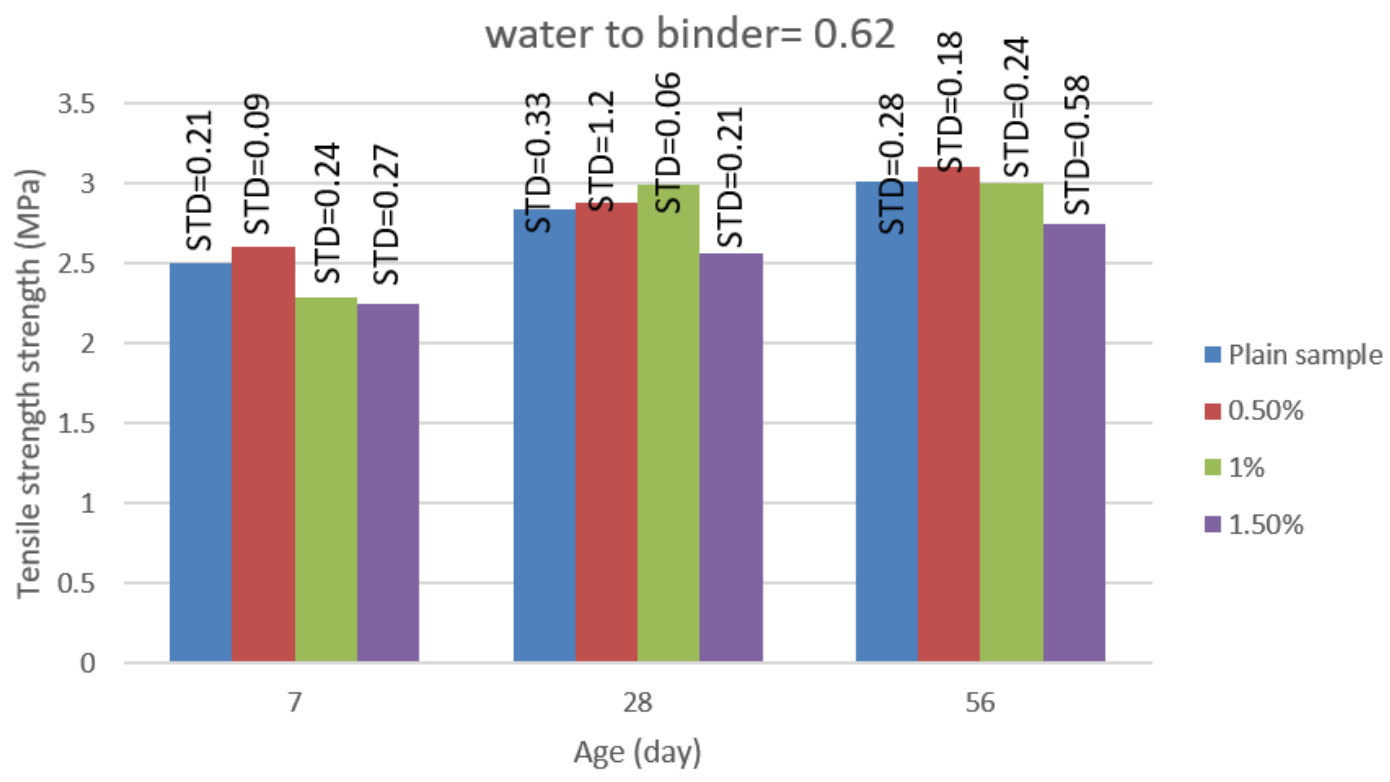

(c)

Figure 9. Tensile strength vs. age for water-to-binder ratios of (a) 0.44 , (b) 0.49 , and (c) 0.62.

\subsection{Permeability Test}

A total of 78 cylindrical samples are placed in a permeability gage and subjected to 5 bar water pressure for $24 \mathrm{~h}$. Then, the splitting test is conducted, and the depth of water penetration is measured. The results of the permeability test on the 78 cylindrical samples are demonstrated in Figure 10 for different water-to-binder ratios. As seen in Figure 10, the positive effect of nano- $\mathrm{MgO}$ on permeability is available in all samples. The most optimal result (minimum amount of permeability) belonged to the water-to-binder ratio equal to 0.44 for samples with $1 \%$ nano-MgO. As expected, the addition of nano-powder filled the nanosized pores and reduced water penetration. In addition, the expansive feature of nano-MgO plays an effective role in the reduction of concrete permeability. By the completion of the hydration process of nano- $\mathrm{MgO}$, the product of hydration needs more space, pores of the concrete are occupied, and as a result, permeability comes down. As seen in Figure $10 \mathrm{a}, 1 \%$ of nano-MgO is the optimum amount of this nanomaterial for the 0.44 water-to-binder ratio. It reduces the permeability of concrete up to $63 \%$. In addition, $1.5 \%$ of nano- $\mathrm{MgO}$ has reduced permeability, but the reduction is not as strong as that of $1 \%$ nano $\mathrm{MgO}$. As observed in Figure 10, increasing the water-to-binder ratio causes the optimum amount of nano-MgO to differ. Regarding Figure $10 \mathrm{~b}, \mathrm{c}$, the best results are gained with $1.5 \%$ nano-MgO for samples cured for 56 days. Regarding the high standard deviation of these samples (STD $=1.2)$ in comparison with other samples, it seems that the least permeability for this group $(\mathrm{w} / \mathrm{c}=0.62$, nano- $\mathrm{MgO}=1.5 \%$ and samples cured for 56 days) is not reliable; as a result, $0.5 \%$ of nano-MgO plays the most efficient role in decreasing the permeability, which is $26 \%$ less than that of plain samples. 


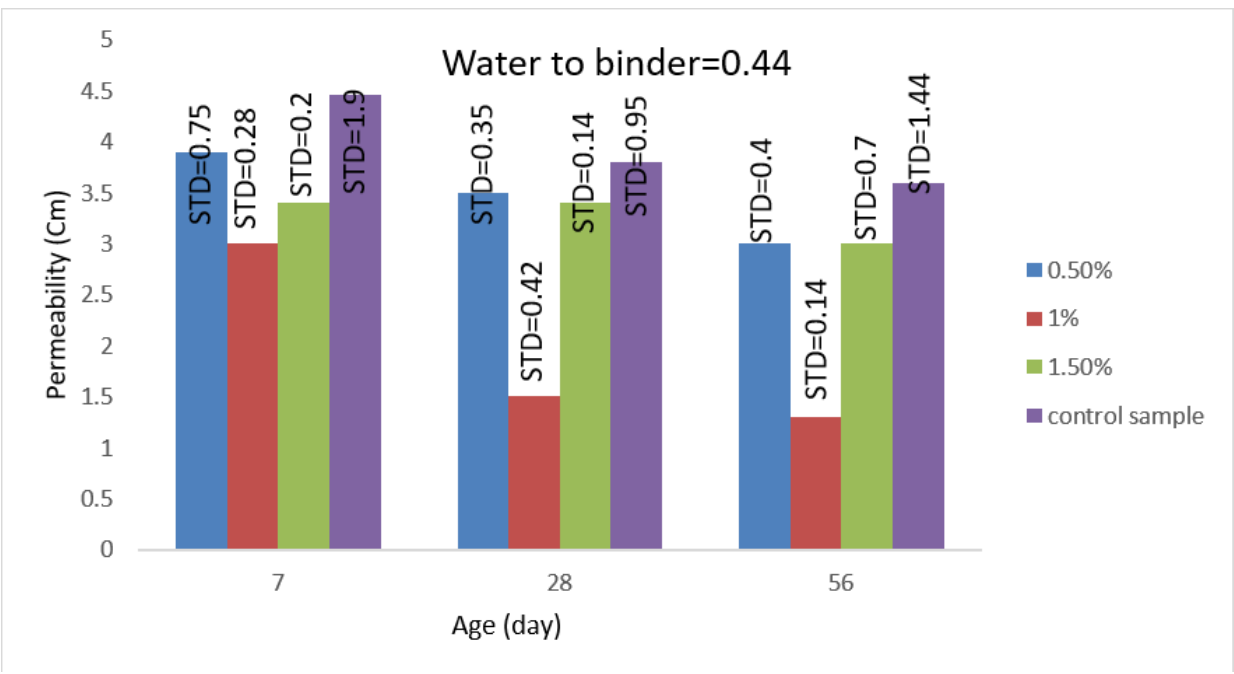

(a)

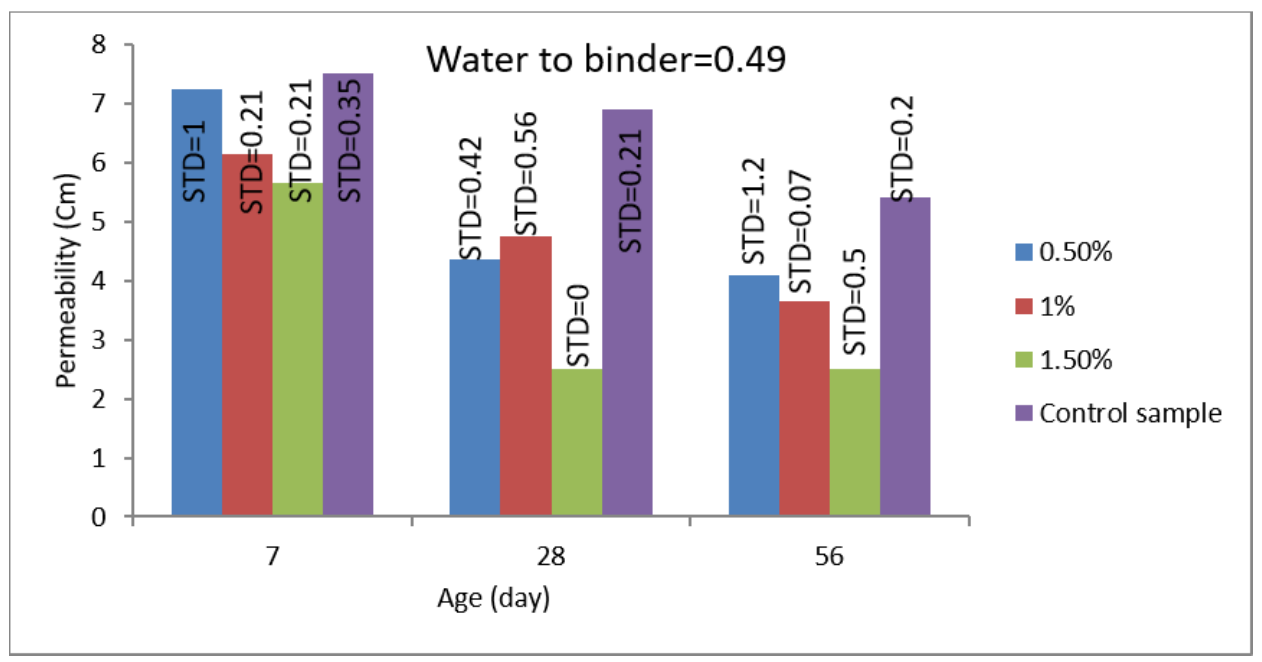

(b)

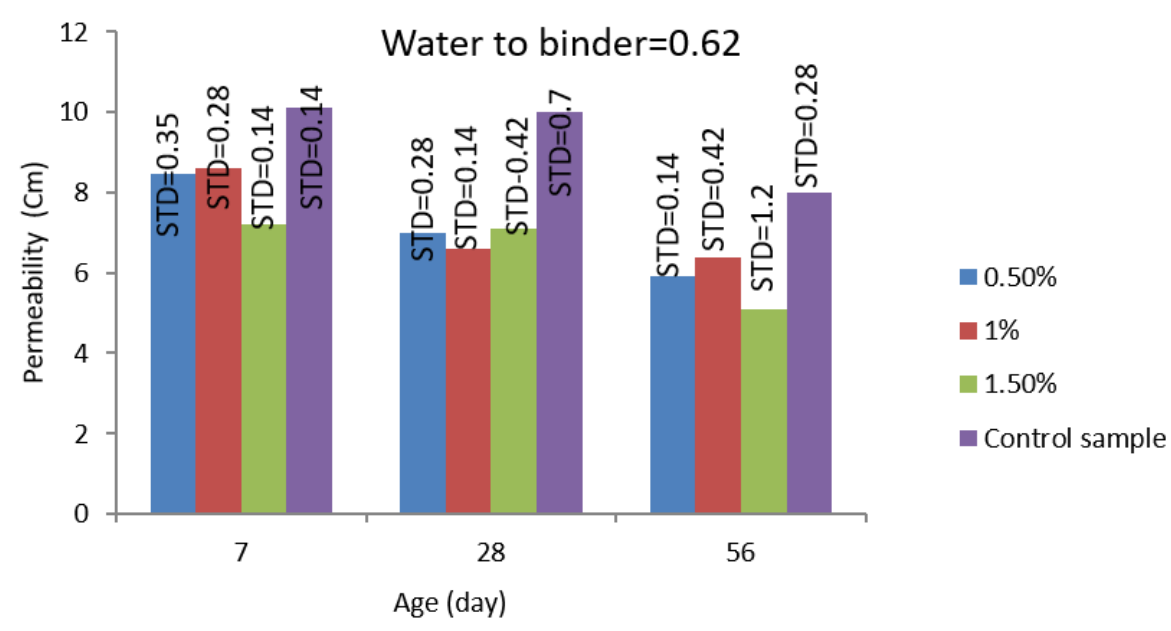

(c)

Figure 10. Permeability vs. age for water-to-binder ratios of (a) 0.44 , (b) 0.49 , and (c) 0.62. 


\subsection{Modeling and Discussion}

A mathematical formulation is presented to numerically assess the effects of utilized materials on the concrete properties. To fulfill this purpose, the GEP method is applied. GeneXpro tools 5.0 [41] was utilized to generate the mathematical expressions between the variables and the objectives. For every objective, eight models were run with different properties such as the number of chromosomes, number of head size, linking function, and number of constants per gene (Table 5). The dataset is divided into two parts by the GEP algorithm randomly; $80 \%$ of the dataset is training data and $20 \%$ is testing data. Testing data do not have any role in the training process and building of the model. In Figures 11-13, the best results of GEP are shown as ETs, in which $\mathrm{d}_{0}, \mathrm{~d}_{1}, \mathrm{~d}_{2}$, and $\mathrm{d}_{3}$ represent the percentage of nano-MgO, water-to-binder ratio, curing age of concrete, and superplasticizer percentage, respectively.

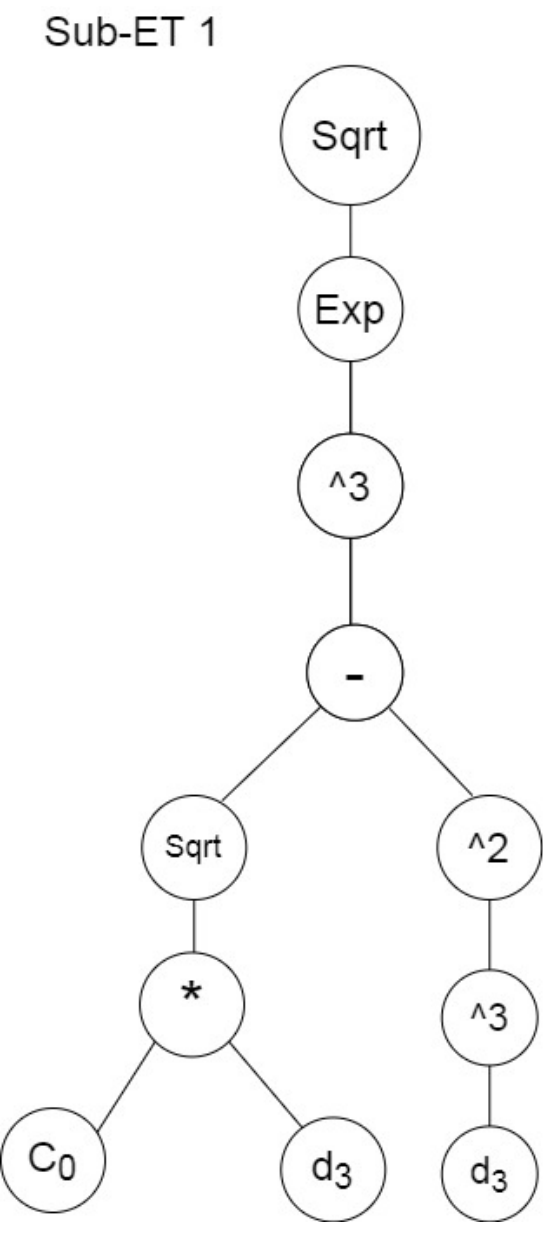

(a)

Figure 11. Cont. 


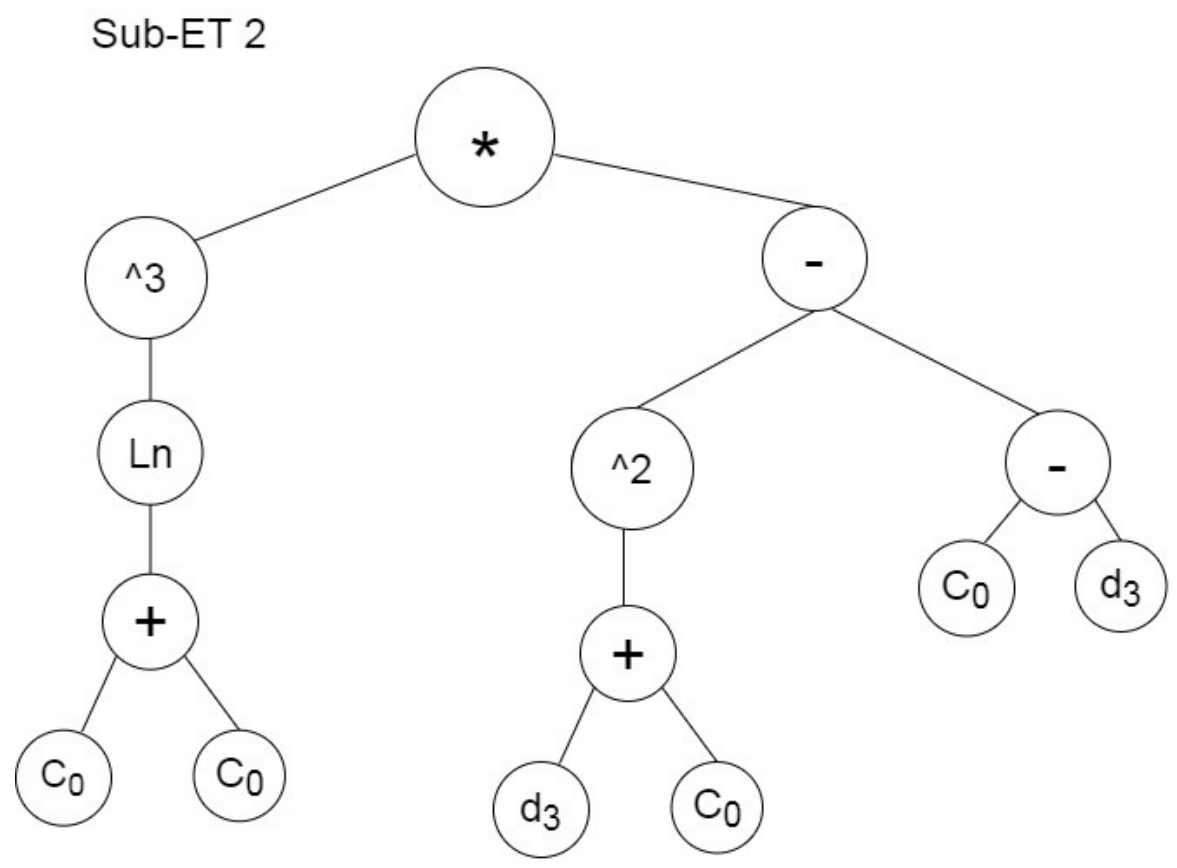

(b)

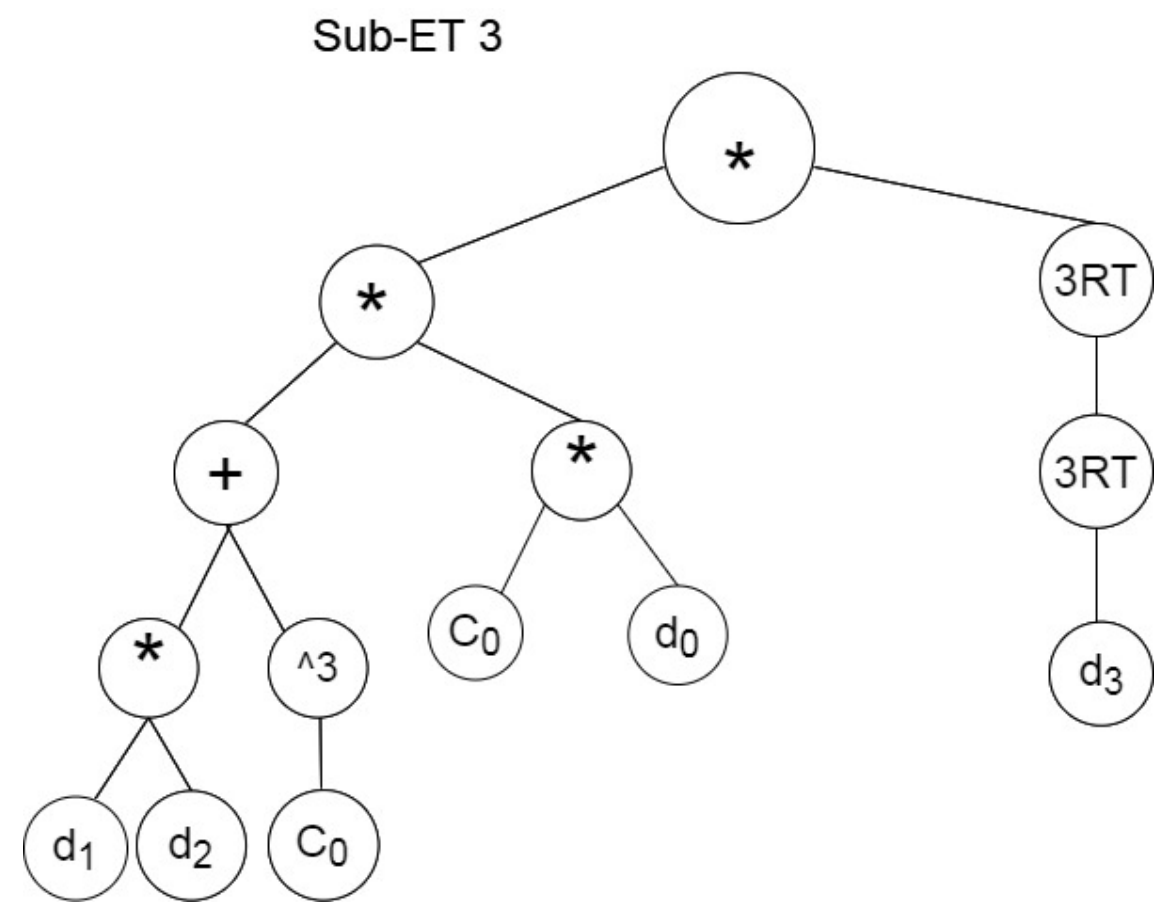

(c)

Figure 11. Expression trees (ETs) of Gene Expression Programming (GEP1) for compressive strength (a) sub-ET1 (b) sub-ET2, (c) sub-ET3. 


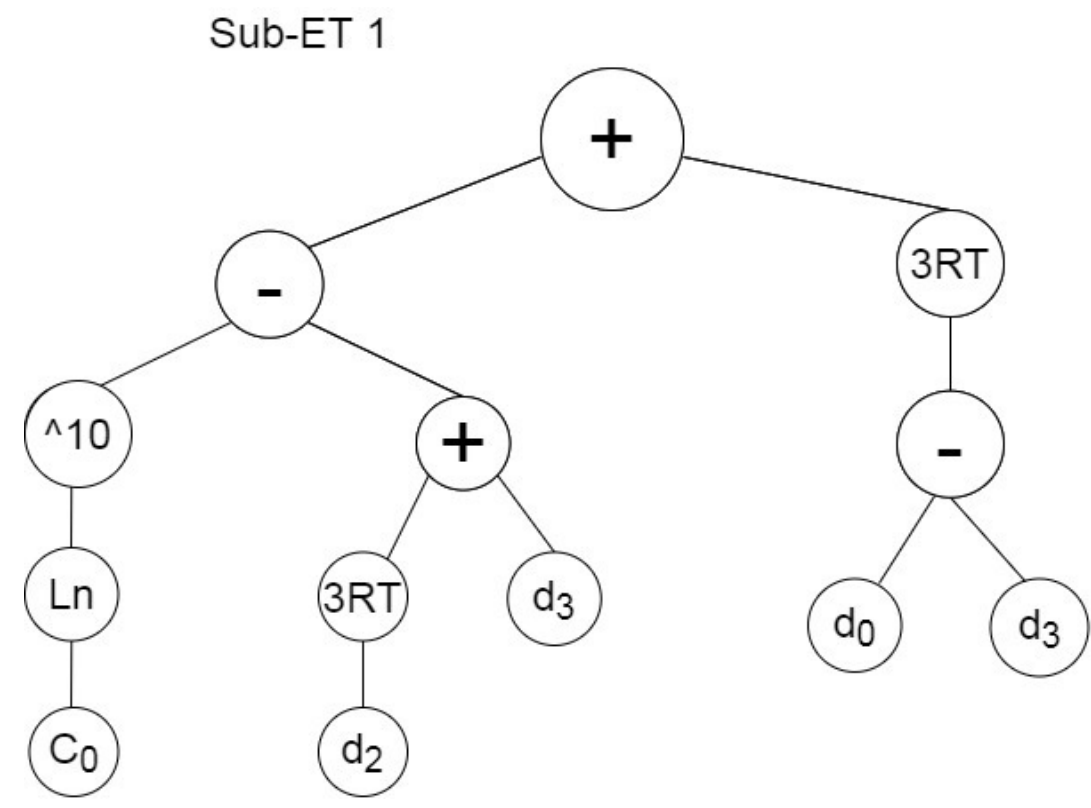

(a)

Sub-ET 2

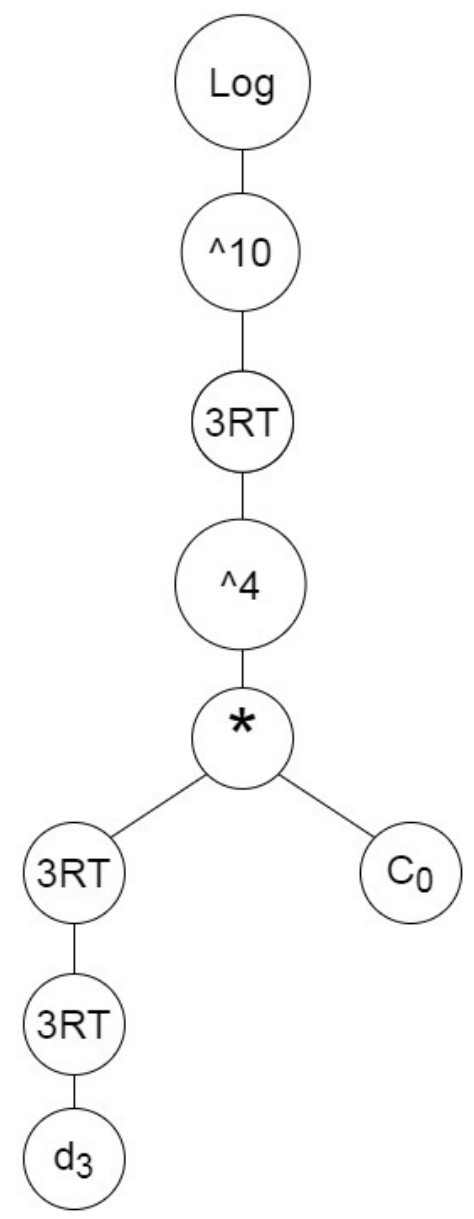

(b)

Figure 12. Cont. 


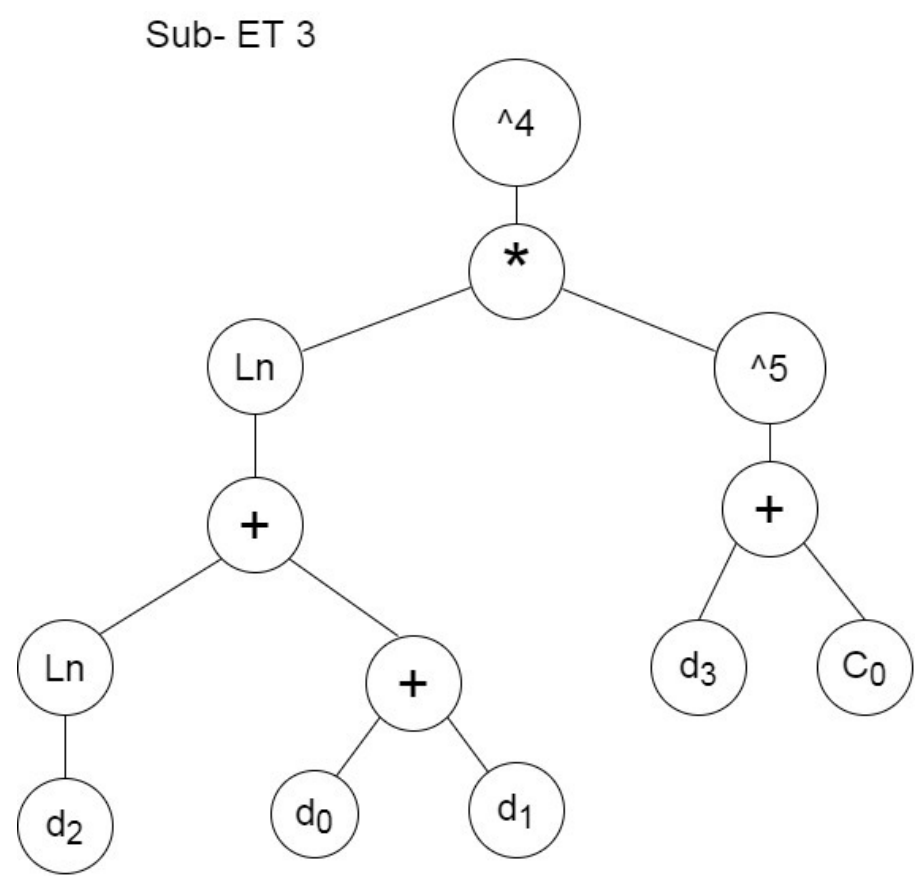

(c)

Figure 12. Expression trees of GEP1 for tensile strength (a) sub-ET1, (b) sub-ET2, (c) sub-ET3.

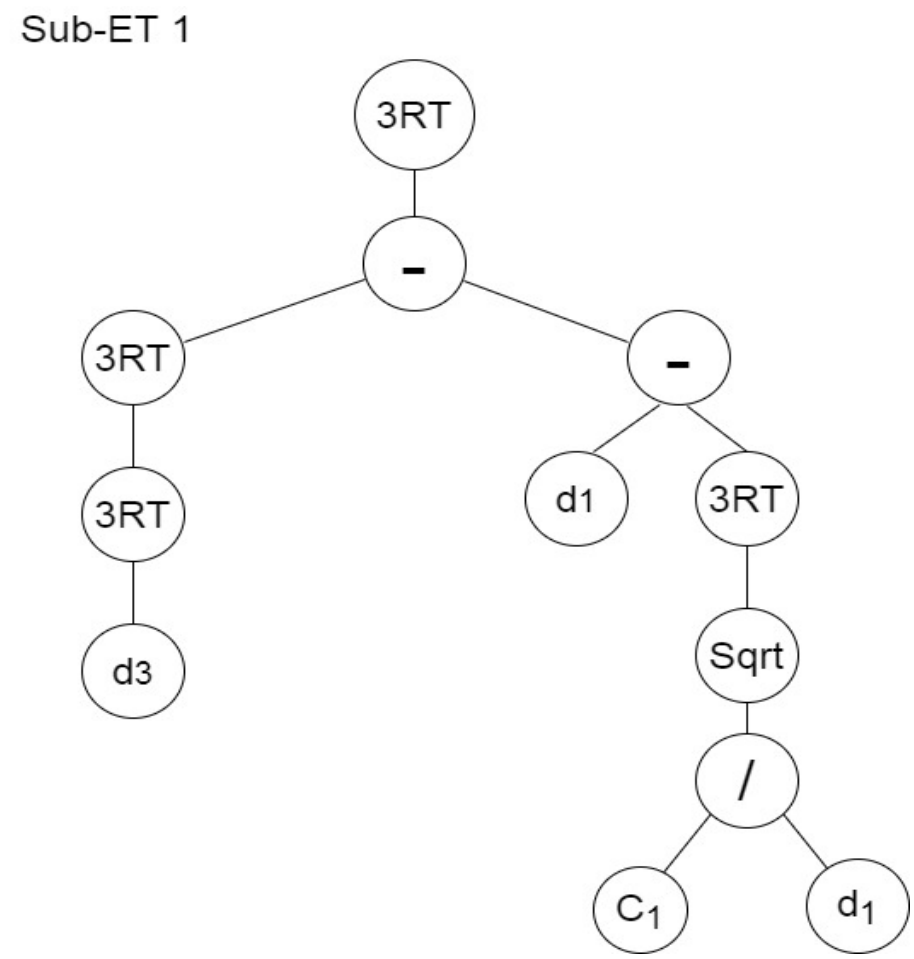

(a)

Figure 13. Cont. 


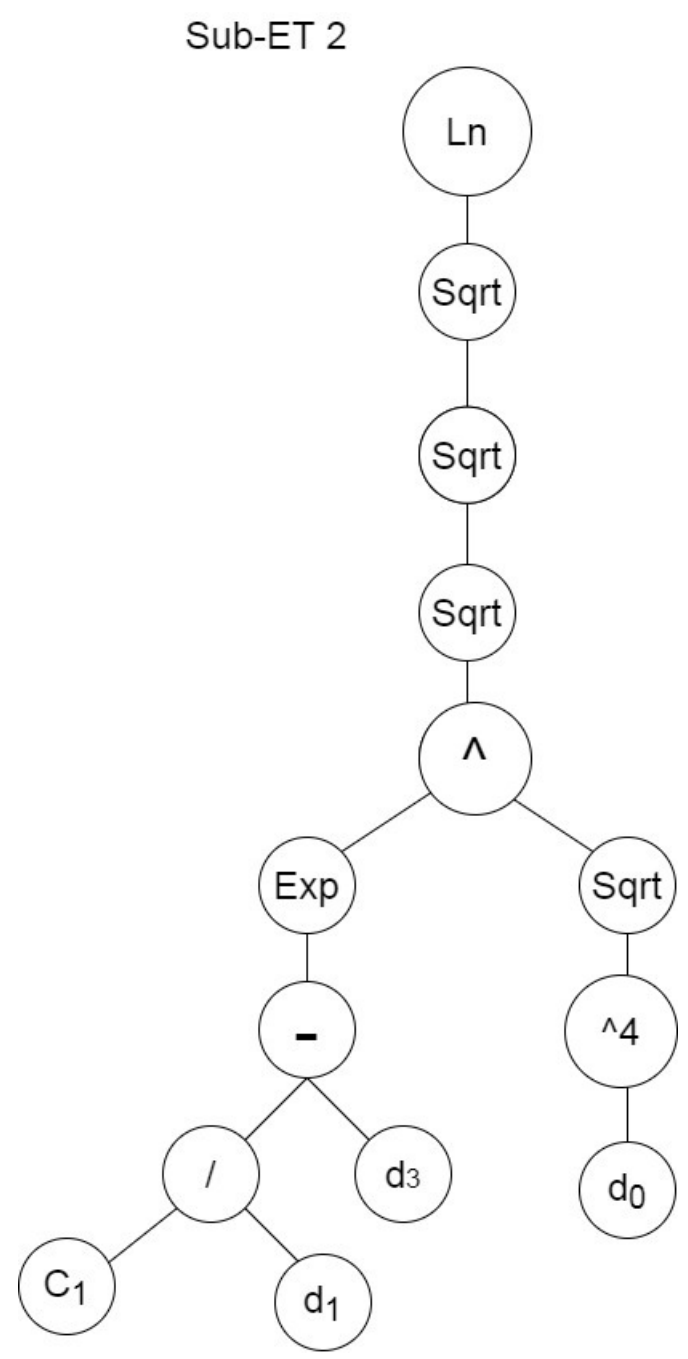

(b)

Figure 13. Cont. 


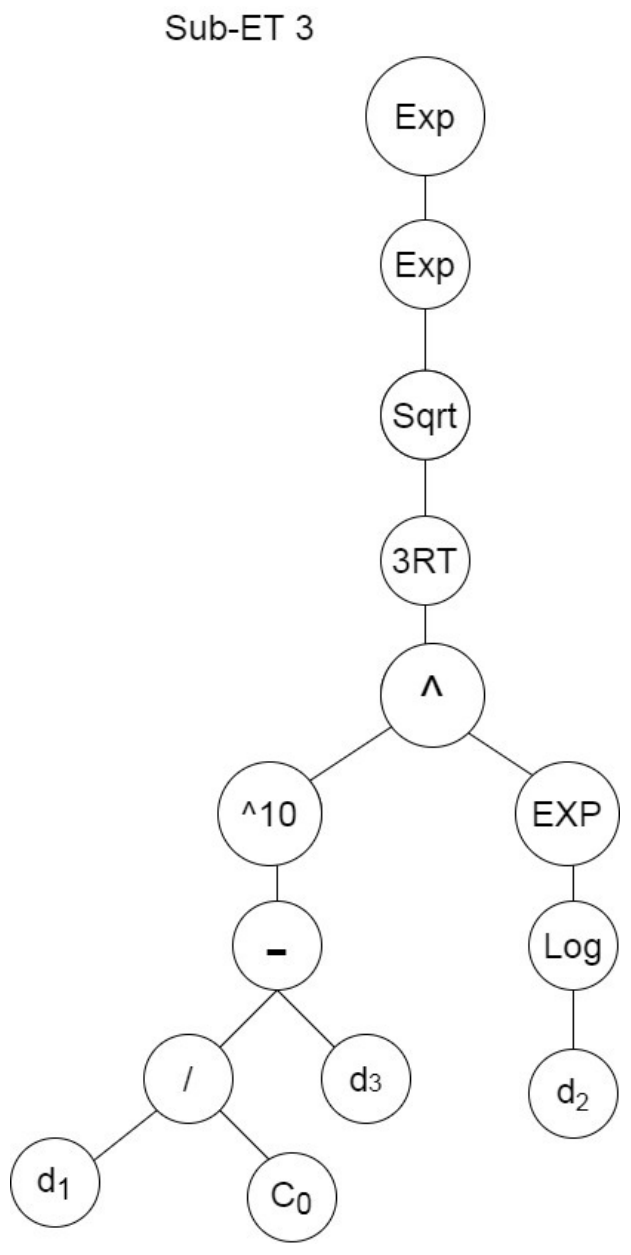

(c)

Figure 13. Expression trees of GEP6 for permeability (a) sub-ET1, (b) sub-ET2, (c) sub-ET3.

Tables 8-10 show the best mathematical formulation for the prediction of the compressive strength, tensile strength, and permeability, respectively. Every formulation consists of three genes that are linked to each other by linking functions such as addition or multiplication. For finding the proper formulation, GEP uses different operators such as powers, Sqrt, $\mathrm{e}^{\hat{\prime}}, \mathrm{Ln}, \mathrm{Log}$, etc. All four variables are utilized in formulations; it shows that selected variables are effective in the performance of the concrete.

Table 8. The mathematical formulation of compressive strength of concrete samples containing nano-MgO proposed by the GEP tool.

\begin{tabular}{|c|c|c|}
\hline GEP Model & Predictive Equati & on of GEP for Compressive Strength \\
\hline \multirow[t]{2}{*}{ GEP 1} & $\sqrt{\left(e^{\left(\sqrt{C_{0} \times d_{3}}-d_{3}\right)^{3}}\right)}$ & $\begin{array}{l}+\left(\ln 2 C_{0}\right)^{3} \times\left[\left(d_{3}+C_{0}\right)^{2}+d_{3}-C_{0}\right] \\
+\left[\left(d_{1} \times d_{2}\right)+C_{0}^{3}\right] \times\left(C_{0} \times d_{0}\right) \times d_{3}^{1 / 9}\end{array}$ \\
\hline & $\begin{array}{l}\text { Gene1 } \\
C_{0}=7.8328070267 \\
\text { Gene2 } \\
C_{0}=5.5759430919 \\
\text { Gene3 } \\
C_{0}=-2.53441575\end{array}$ & $\begin{array}{l}0388 \\
1839 \\
642642\end{array}$ \\
\hline
\end{tabular}


Table 9. The mathematical formulation of tensile strength of concrete samples containing nano-MgO proposed by the GEP tool.

\begin{tabular}{|c|c|}
\hline GEP Model & Predictive Equation of GEP for Tensile Strength \\
\hline GEP 1 & $\begin{aligned} {\left[10^{\left(\ln C_{0}\right)}-\left(\sqrt[3]{d_{2}}\right.\right.} & \left.\left.+d_{3}\right)+\sqrt[3]{\left(d_{0}-d_{3}\right)}\right]+\left[\left(d_{3}\right)^{1 / 9} \times C_{0}\right]^{4 / 3} \\
& +\left[\left[\ln \left[\left(\ln d_{2}\right)+\left(d_{0}+d_{1}\right)\right]\right] \times\left(d_{3}+C_{0}\right)^{5}\right]^{4}\end{aligned}$ \\
\hline & $\begin{array}{l}\text { Gene } 1 \\
C_{0}=4.22343540914285 \\
\text { Gene } 2 \\
C_{0}=-6.93788025316173 \\
\text { Gene } 3 \\
C_{0}=2.54902402849616 \times 10^{-2}\end{array}$ \\
\hline
\end{tabular}

Table 10. The mathematical formulation of permeability of concrete samples containing nano-MgO proposed by the GEP tool.

\begin{tabular}{cc}
\hline GEP Model & Predictive Equation of GEP for Permeability \\
\hline GEP 6 & $\sqrt[3]{\left[\left(d_{3}\right)^{1 / 9}-\left(d_{1}-\left(\frac{C_{1}}{d_{2}}\right)^{1 / 6}\right)\right]}+\ln \left[\left[e^{\left(\frac{C_{1}}{d_{1}}-d_{3}\right)}\right]^{d_{0}^{2}}\right]^{1 / 8}+e^{e^{10}\left[\frac{1}{6} \times e^{\left.\log d_{2} \times\left(\frac{d_{1}}{C_{0}}-d_{3}\right)\right]}\right.}$ \\
\hline Gene 1 \\
$C_{0}=-1.75695059053316 \times 10^{-2}$ \\
$C_{1}=2.79598577259418$ \\
Gene 2 \\
$C_{0}=1.36482746154668$ \\
$C_{1}=-1.5475468457684$ \\
Gene 3 \\
$C_{0}=-2.50445673280235$ \\
$C_{1}=7.70746482741783$ \\
\hline
\end{tabular}

Regression analysis is a type of statistical modeling that estimates the relation between dependent variables and independent variables. Linear regression is the most common regression. The aim of linear regression is finding the best fitting line to data. Figures 14-16 depict the regression diagrams by experimental data and the predicted data for the compressive strength, tensile strength, and permeability, respectively. The horizontal axis shows predicted values by GEP, and the vertical axis is experimental data. The error is named "coefficient of determination" and is shown by $\mathrm{R}^{2}$. An ideal line has $\mathrm{R}^{2}=1$, which means that the predicted values and real data are the same. The model is created by a training dataset, and it is examined by the testing dataset. The formulation of the compressive strength has an $\mathrm{R}^{2}$ value of 0.98 for both the training and testing data. For the tensile strength formula, this value is 0.97 and 0.96 for the training and testing data, respectively. From Table 11, it can be concluded that GEP is an applicable and beneficial tool for predicting the concrete properties, which has been confirmed by the results. 


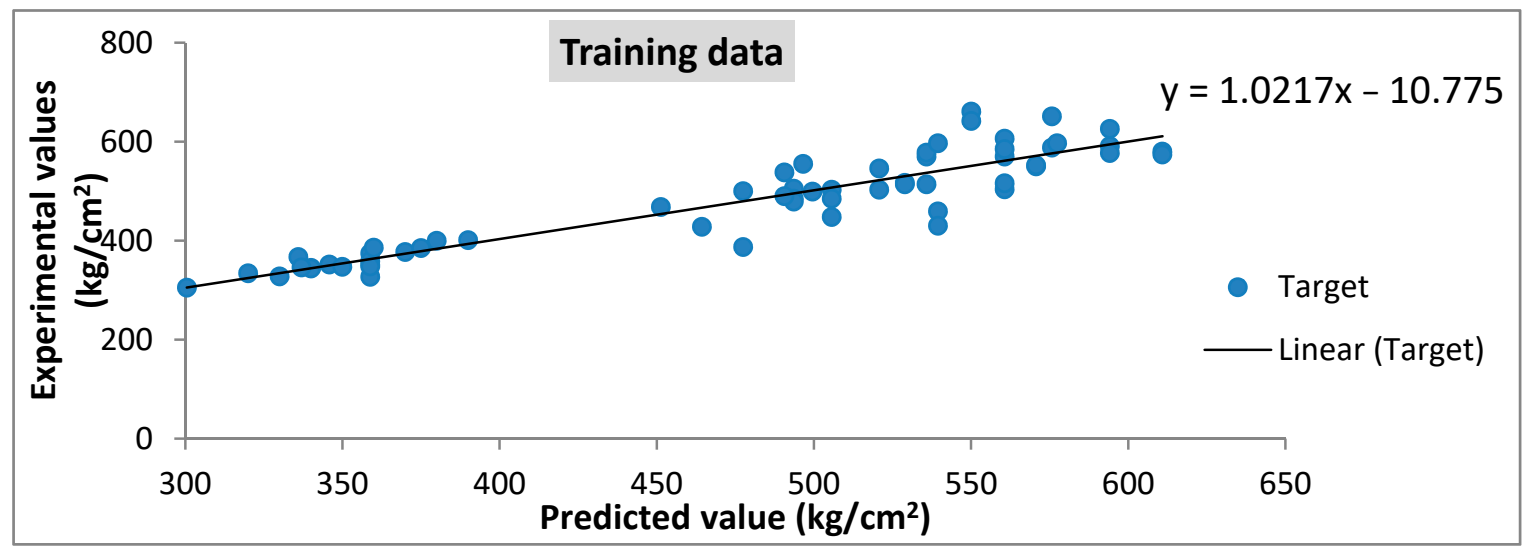

(a)

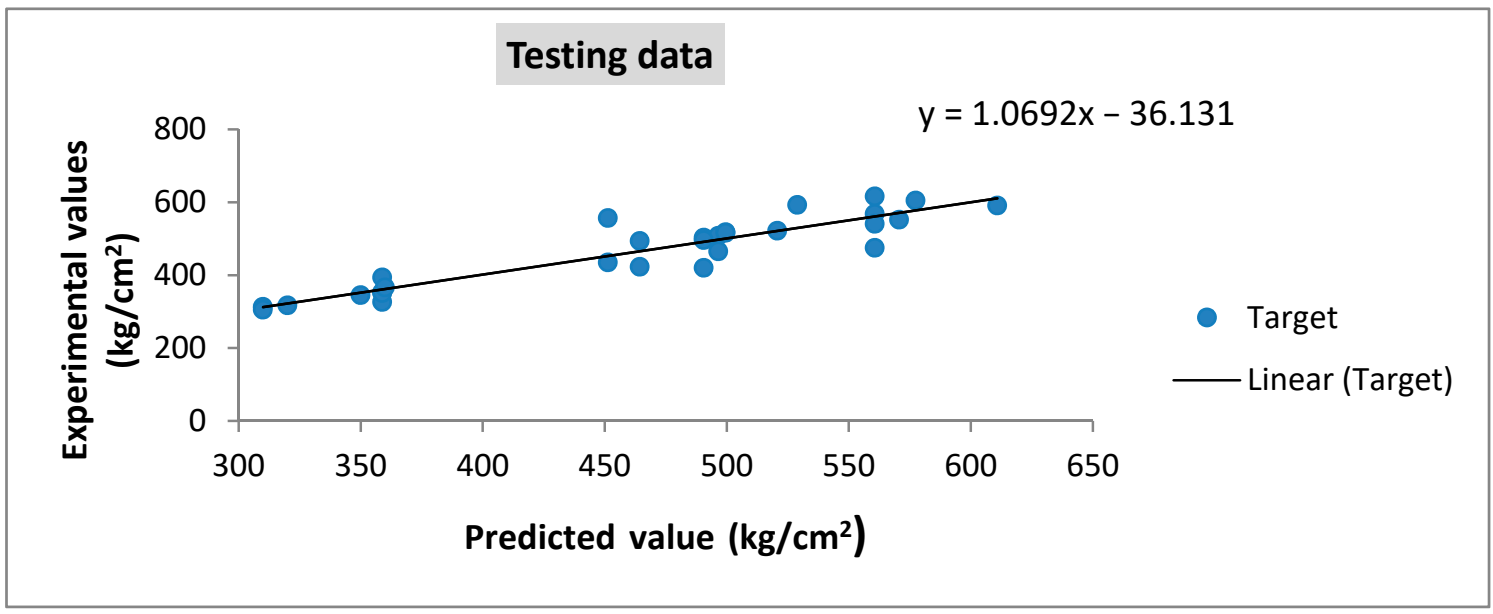

Figure 14. Regression chart for the GEP1 prediction model of compressive strength: (a) training data, (b) testing data.

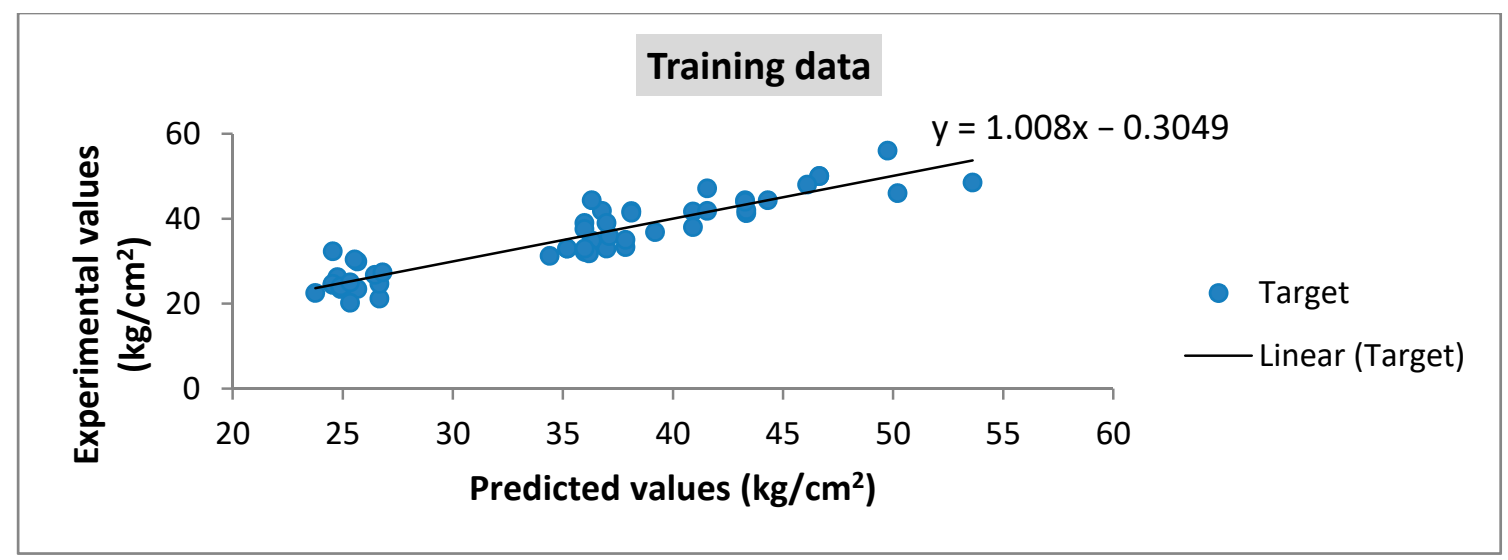

(a)

Figure 15. Cont. 


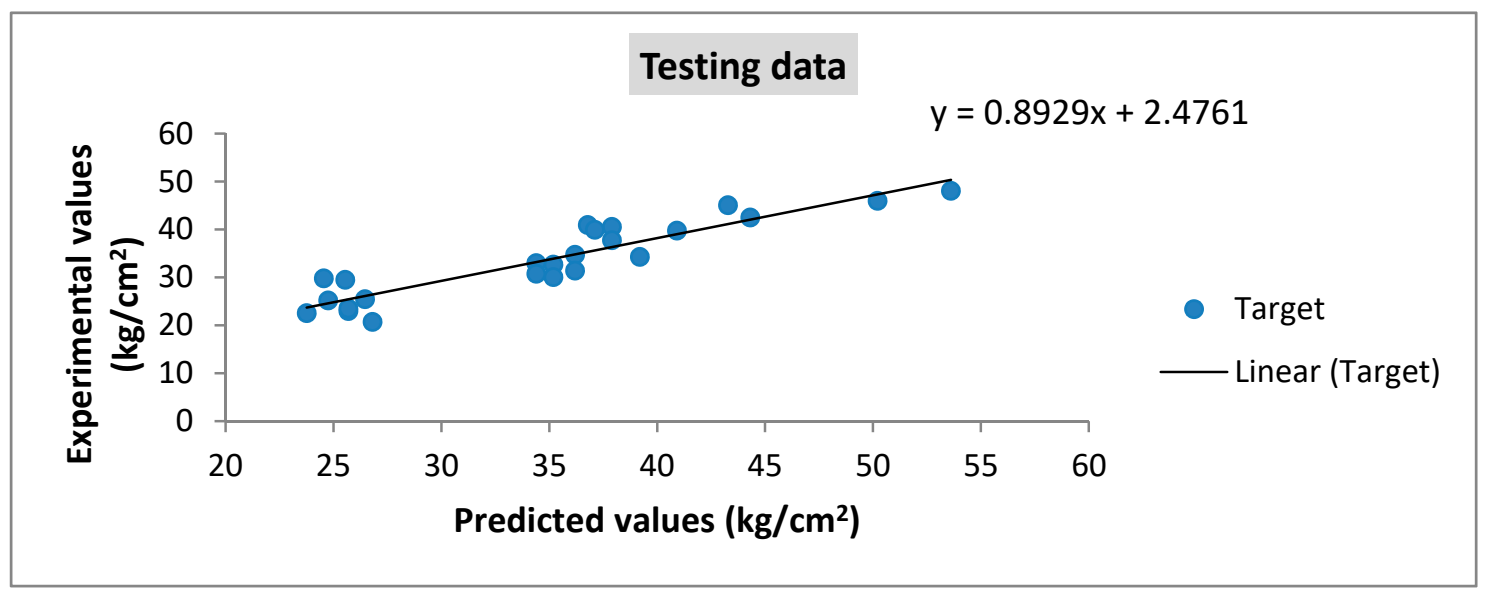

(b)

Figure 15. Regression chart for the GEP1 prediction model of tensile strength: (a) training, (b) testing data.

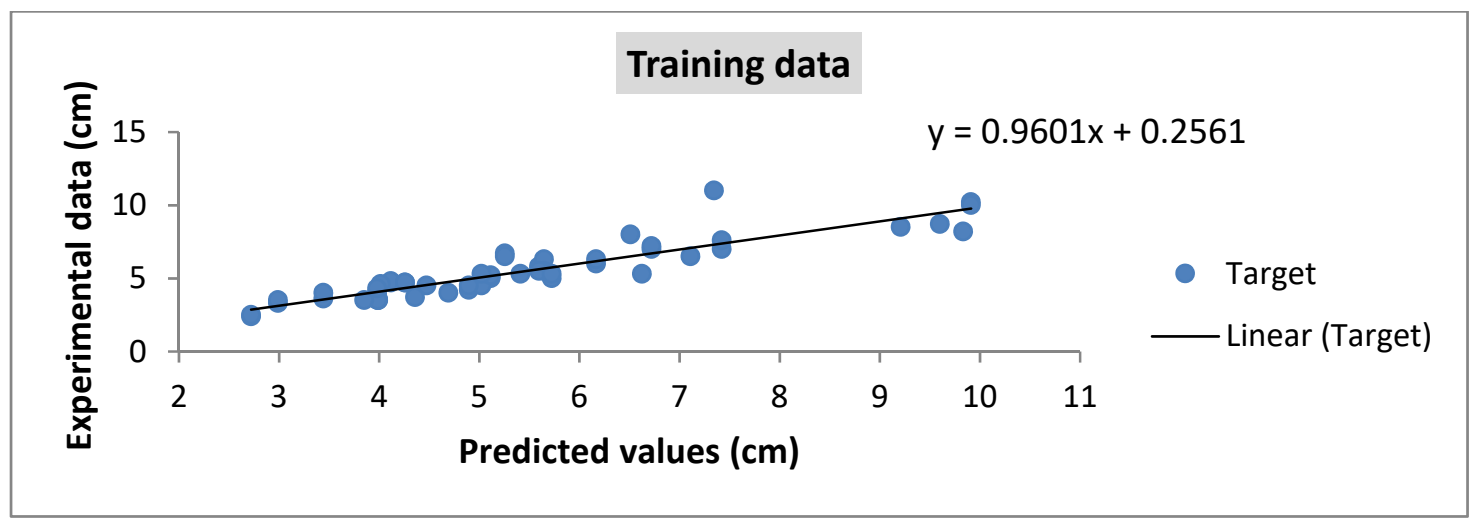

(a)

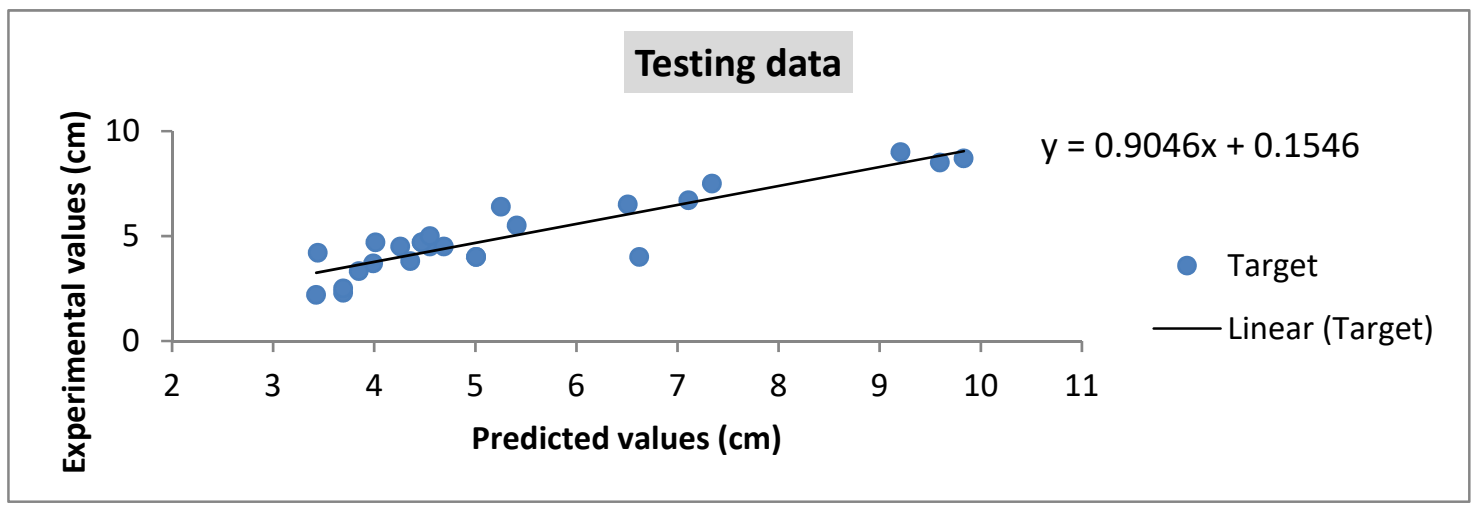

(b)

Figure 16. Regression chart for GEP6 prediction model of permeability: (a) training data, (b) testing data. 
Table 11. Statistical errors for best models of GEP.

\begin{tabular}{ccc}
\hline GEP Model & $\mathbf{R}^{\mathbf{2}}$ & $\begin{array}{c}\text { Root Mean Square Error } \\
\text { (RMSE) (Fitness Value) }\end{array}$ \\
\hline \multirow{2}{*}{ GEP1 for compressive strength } & Training $=0.98$ & Training $=24.16$ \\
& Testing $=0.98$ & Testing $=24.28$ \\
\hline \multirow{2}{*}{ GEP1 for tensile strength } & Training $=0.97$ & Training $=227.1$ \\
& Testing $=0.96$ & Testing $=225.25$ \\
\hline \multirow{2}{*}{ GEP6 for permeability } & Training $=0.96$ & Training $=558.14$ \\
& Testing $=0.95$ & Testing $=528.16$ \\
\hline
\end{tabular}

\section{Conclusions}

In this study, the effect of nano- $\mathrm{MgO}$ on the durability of normal concrete under freezethaw conditions is investigated. A total of 98 cubic $10 \times 10 \times 10$ concrete samples are created for the compressive strength test, while 78 cylindrical concrete $10 \times 20$ samples are considered for the tensile strength and permeability tests. All of the samples are subjected to 300 freeze-thaw cycles. Variables of the study are the water-to-binder ratio $(0.44,0.49$, $0.62)$, percentage of nano- $\mathrm{MgO}(0,0.5 \%, 1 \%, 1.5 \%)$, curing period $(7,28,56$ days $)$, and percentage of superplasticizer $(0,0.5 \%, 1 \%)$. The results are summarized below.

By comparing the results of the compressive strength for the three water-to-binder ratios, the maximum compressive strength belongs to the water-to-binder ratio of 0.44 with samples containing $1 \%$ nano- $\mathrm{MgO}$ that were cured for 56 days. This amount of nano-MgO can enhance the compressive strength to $63 \mathrm{MPa}$, which is $9.12 \%$ more than the control samples $(57.7 \mathrm{MPa})$ on average. For the water-to-binder ratio of 0.49 , the best compressive strength is gained by the sample with $1.5 \%$ nano- $\mathrm{MgO}(57.4 \mathrm{MPa})$, which is $17 \%$ more than the control samples (49 MPa). The least positive effect of nano- $\mathrm{MgO}$ on the compressive strength of concrete samples occurs in samples with a water-to-binder ratio of 0.62 with $0.5 \%$ nano- $\mathrm{MgO}$ ( $2.6 \%$ increase). The best results of tensile strength and permeability can be gained by the same amounts of nano- $\mathrm{MgO}$. As an example, the addition of $1 \%$ nano- $\mathrm{MgO}$ to the mixture with a water-to-binder ratio of 0.44 can increase the tensile strength $10.6 \%$ more than the control sample and decrease the permeability by $63 \%$ in comparison to the control samples. The same trend of effect is gained from the permeability test results.

For assessment of the results numerically and proposing a mathematical formulation for predicting the mechanical properties of concrete with nano-MgO, the GEP method is applied. Different models are examined, and the best models are chosen regarding statistical results. For the compressive and tensile strengths, GEP1 is selected as the best model in which the amount of $\mathrm{R}^{2}$ is 0.98 and 0.97 for training and test data, respectively. For permeability, GEP6 is introduced as the best model, while it has an $R^{2}$ of 0.96 and 0.95 for the training and testing data, respectively. GEP can provide a simple and very useful formulation that can be used easily. As a result of the acceptable accuracy of the models provided by GEP, they are applicable in further designation and investigation programs, and it is useful for the prediction of the mechanical properties of the concrete with nano-MgO in cold regions.

Author Contributions: The authors confirm contribution to the paper as follows: Study conception and design: A.F.A.; S.T.; M.Y. Data collection: M.Y., A.F.A. Analysis and interpretation of results: A.F.A.; S.T.; M.Y.; Draft manuscript preparation: M.Y., A.F.A., S.T., A.H.G. All authors have read and agreed to the published version of the manuscript.

Funding: Not applicable.

Institutional Review Board Statement: Not applicable.

Informed Consent Statement: Not applicable.

Data Availability Statement: The data presented in this study are available on request from the corresponding author. 
Conflicts of Interest: The authors declare no conflict of interest.

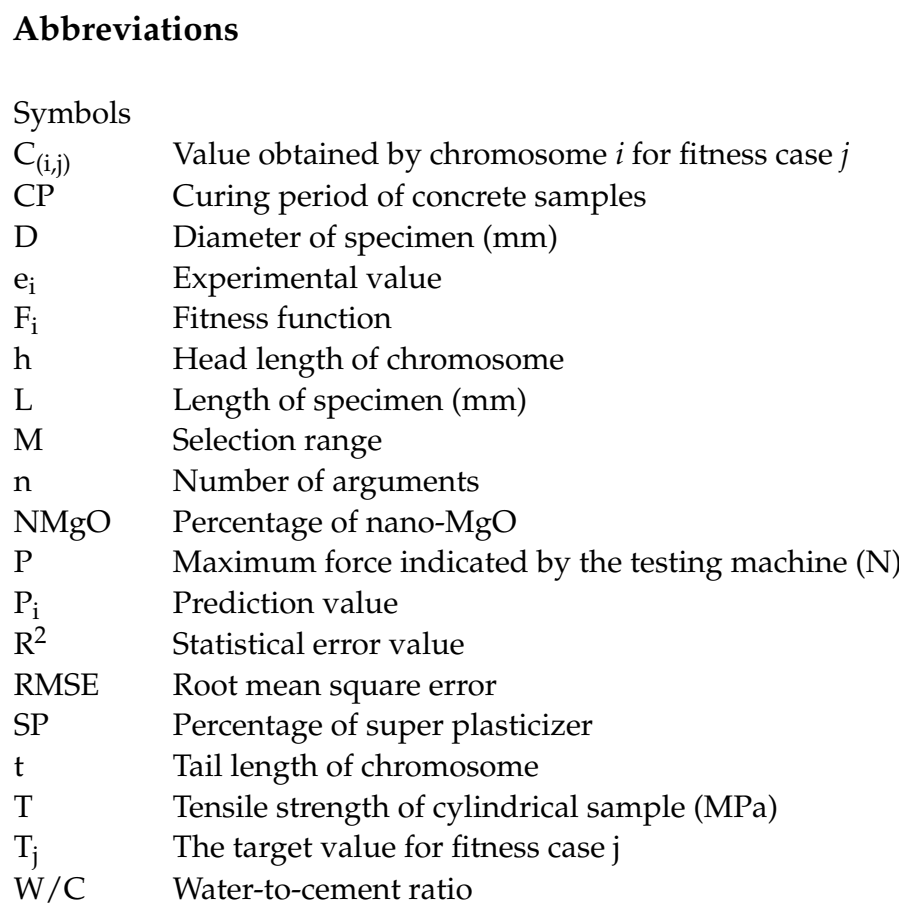

\section{References}

1. Powers, T.C. A Working Hypothesis for Further Studies of Frost Resistance of Concrete. J. Am. Concr. Inst. 1945, 16, $245-272$.

2. Ebrahimi, K.H.; Daiezadeh, M.J.; Zakertabrizi, M.; Zahmatkesh, F.; Habibnejad Korayem, A. A review of the impact of micro- and nanoparticles on freeze-thaw durability of hardened concrete: Mechanism perspective. Constr. Build. Mater. 2018, 186, 1105-1113. [CrossRef]

3. Du, L.; Folliard, K.J. Mechanisms of air entrainment in concrete. Cem. Concr. Res. 2005, 35, 1463-1471. [CrossRef]

4. Halbiniak, J.; Langier, B. Research on the frost resistance of concretes modified with fly ash. Teka Kom. Motoryz. Energetyki Rolnictwa. 2014, 14, 23-30.

5. Chung, C.W.; Shon, C.S.; Kim, Y.S. Chloride ion diffusivity of fly ash and silica fume concretes exposed to freeze-thaw cycles. Constr. Build. Mater. 2010, 24, 1739-1745. [CrossRef]

6. Cwirzen, A.; Habermehl-Cwirzen, K. The Effect of Carbon Nano- and Microfibers on Strength and Residual Cumulative Strain of Mortars Subjected to Freeze-Thaw Cycles. J. Adv. Concr. Tech. 2013, 11, 80-88. [CrossRef]

7. Wong, H.S.; Barakat, R.; Alhilali, A.; Saleh, M.; Cheeseman, C.R. Hydrophobic concrete using waste paper sludge ash. Cem. Concr. Res. 2015, 70, 9-20. [CrossRef]

8. Du, H.; Du, S.; Liu, X. Durability performances of concrete with nano-silica. Constr. Build. Mater. 2014, 73, 705-712. [CrossRef]

9. Wang, B.; Wang, L.; Lai, F. Freezing resistance of HPC with nano-SiO ${ }_{2}$. J. Wuhan Univ. Technol. Mater. Sci. 2008, 23, 85-88. [CrossRef]

10. Fan, Y.; Zhang, S.; Wang, Q.; Shah, S.P. Effects of nano-kaolinite clay on the freeze-thaw resistance of concrete. Cem. Concr. Compos. 2015, 62, 1-12. [CrossRef]

11. Gonzalez, M.; Tighe, S.L.; Hui, K.; Rahman, S.; Lima, A.O. Evaluation of freeze-thaw and scaling response of nano concrete for Portland Cement Concrete (PCC) pavements. Constr. Build. Mater. 2016, 120, 465-472. [CrossRef]

12. Yanturina, R.A.; Trofimov, B.Y.; Ahmedjanov, R.M. The Influence of Graphite-Containing Nano-Additives on Thermo-Frost Resistance of Concrete. Proc. Eng. 2017, 206, 869-874. [CrossRef]

13. Shahrajabian, F.; Behfarnia, K. The effects of nano particles on freeze and thaw resistance of alkali-activated slag concrete. Constr. Build. Mater. 2018, 176, 172-178. [CrossRef]

14. Kalhori, H.; Bagherzadeh, B.; Bagherpour, R.; Akhlaghi, M.A. Experimental study on the influence of the different percentage of nanoparticles on strength and freeze-thaw durability of shotcrete. Constr. Build. Mater. 2020, 256, 119470. [CrossRef]

15. Nobre, J.; Hawreen, A.; Evangelista, L.; Bravo, M. Magnesia (MgO) Production and Characterization, and Its Influence on the Performance of Cementitious Materials: A Review. Materials 2020, 13, 4752. [CrossRef]

16. Mo, L.; Deng, M.; Tang, M.; Al Tabbaa, A. MgO expansive cement and concrete in China: Past, present and future. Cem. Concr. Res. 2014, 57, 1-12. [CrossRef] 
17. Moradpour, R.; Taheri-Nassaj, E.; Parhizkar, T.; Ghodsian, M. The effects of nanoscale expansive agents on the mechanical properties of non-shrink cement-based composites: The influence of nano-MgO addition. Compos. Part B 2013, 5, 193-202. [CrossRef]

18. Dung, N.; Unluer, C. Improving the performance of reactive MgO cement-based concrete. Constr. Build. Mater. 2016, 126, 747-758. [CrossRef]

19. Kabir, H.; Hooton, R. Evaluating soundness of concrete containing shrinkage-compensating MgO admixtures. Constr. Build. Mater. 2020, 253, 119141. [CrossRef]

20. Gandomi, A.H.; Alavi, A.H.; Ryan, C. Handbook of Genetic Programming Applications; Springer: Cham, Switzerland, 2015.

21. Ferreira, C. Gene expression programming: A new adaptive algorithm for solving problems. Complex. Syst. 2011, 13, 87-129.

22. Ferreira, C. Gene Expression Programming in Problem Solving. In Soft Computing and Industry; Roy, R., Köppen, M., Ovaska, S., Furuhashi, T., Hoffmann, F., Eds.; Springer: London, UK, 2002. [CrossRef]

23. Ferreira, C. Gene Expression Programming: Mathematical Modeling by an Artificial Intelligence, 2nd ed.; Springer: Berlin/Heidelberg, Germany, 2006.

24. Gandomi, A.H.; Alavi, A.H.; Mirzahosseini, M.R.; Moghadasnejad, F. Nonlinear Genetic-Based Models for Prediction of Flow Number of Asphalt Mixtures. J. Mater. Civil. Eng. 2011, 23, 248-263. [CrossRef]

25. Ozcan, F. Gene expression programming based formulations for splitting tensile strength of concrete. Constr. Build. Mater. 2012, 26, 404-410. [CrossRef]

26. Gandomi, A.H.; ASCE, S.M.; Karim Babanajad, S.; Alavi, A.H.; Farnam, Y. Novel Approach to Strength Modeling of Concrete under Triaxial Compression. J. Mater. Civil. Eng. 2012, 24, 1132-1143. [CrossRef]

27. Gandomi, A.H.; Alavi, A.H.; Kazemi, S.; Gandomi, M. Formulation of shear strength of slender RC beams using gene expression programming, part I: Without shear reinforcement. Auto. Constr. 2014, 42, 112-121. [CrossRef]

28. Alkroosh, I.; Ammash, H. Soft computing for modeling punching shear of reinforced concrete flat slabs. Ain. Shams. Eng. J. 2015, 6, 439-448. [CrossRef]

29. Mahdinia, S.; Eskandari-Naddaf, H.; Shadnia, R. Effect of cement strength class on the prediction of compressive strength of cement mortar using GEP method. Constr. Build. Mater. 2019, 198, 27-41. [CrossRef]

30. Shahmansouri, A.A.; Akbarzadeh Bengar, H.; Jahani, E. Predicting compressive strength and electrical resistivity of eco-friendly concrete containing natural zeolite via GEP algorithm. Constr. Build. Mater. 2019, 223, 116883. [CrossRef]

31. Farjad Iqbal, M.; Liu, Q.F.; Azim, I.; Zhu, X.; Yang, J.; Javed, M.F.; Rauf, M. Prediction of mechanical properties of green concrete incorporating waste foundry sand based on gene expression programming. J. Hazard. Mater. 2020, 384, 121322. [CrossRef] [PubMed]

32. Behnia, D.; Behnia, M.; Shahriar, K.; Goshtasbi, K. A New Predictive Model for Rock Strength Parameters Utilizing GEP Method. Proc. Eng. 2017, 191, 591-599. [CrossRef]

33. Yeddula, B.S.R.; Karthiyaini, S. Experimental investigations and GEP modelling of compressive strength of ferrosialate based geopolymer mortars. Constr. Build. Mater. 2020, 236, 117602. [CrossRef]

34. ASTM C150. Standard Specification for Portland Cement; ASTM International: West Conshohocken, PA, USA, 2020.

35. ASTM C33/C33M-18. Standard Specification for Concrete Aggregates; ASTM International: West Conshohocken, PA, USA, 2018.

36. Baghdadi, Y.; Youssef, L.Y.; Bouhadir, K.; Harb, M.; Mustapha, S.; Tehrani-Bagha, A. The effects of modified zinc oxide nanoparticles on the mechanical/thermal properties of epoxy resin. J. Appl. Polym. Sci. 2020, 137, 43-49330. [CrossRef]

37. ASTM C666/C666M-15. Standard Test Method for Resistance of Concrete to Rapid Freezing and Thawing; ASTM International: West Conshohocken, PA, USA, 2015. [CrossRef]

38. ASTM C496/C496M-17. Standard Test Method for Splitting Tensile Strength of Cylindrical Concrete Specimens; ASTM International: West Conshohocken, PA, USA, 2017.

39. DIN 1048 (Part-5): German Standard for determination of Permeability of Concrete. Available online: https:/ / www.mystandards. $\mathrm{biz} / \mathrm{standard} /$ din-1048-5-1.6.1991.html (accessed on 1 January 1991).

40. Ferreira, C. Automatically Defined Functions in Gene Expression Programming. In Genetic Systems Programming. Studies in Computational Intelligence; Nedjah, N., Mourelle, L.M., Abraham, A., Eds.; Springer: Berlin/Heidelberg, Germany, 2006. [CrossRef]

41. GEPSOFT, GeneXproTools. Version 5.0. 2013. Available online: https://www.gepsoft.com/ (accessed on 1 May 2013 ). 